\title{
Tank Waste Remediation System Operational Scenario
}

\author{
M. E. Johnson \\ Date Published \\ May 1995
}

Prepared for the U.S. Department of Energy Office of Environmental Restoration and Waste Management

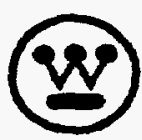

Hanford Operations and Engineering Contractor for the

U.S. Department of Energy under Contract DE-AC06-87RL10930

Approved for Public Release

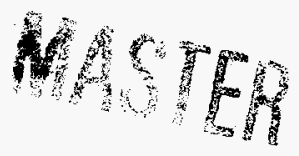





\section{DISCLAIMER}

This report was prepared as an account of work sponsored by an agency of the United States Government. Neither the United States Government nor any agency thereof, nor any of their employees, make any warranty, express or implied, or assumes any legal liability or responsibility for the accuracy, completeness, or usefulness of any information, apparatus, product, or process disclosed, or represents that its use would not infringe privately owned rights. Reference herein to any specific commercial product, process, or service by trade name, trademark, manufacturer, or otherwise does not necessarily constitute or imply its endorsement, recommendation, or favoring by the United States Government or any agency thereof. The views and opinions of authors expressed herein do not necessarily state or reflect those of the United States Government or any agency thereof. 


\section{DISCLAIMER}

Portions of this document may be illegible in electronic image products. Images are produced from the best available original document. 


\section{RELEASE AUTHORIZATION}

Document Number: WHC-EP-0856

Document Title: Tank Waste Remediation System Operational Scenario

Release Date: $\quad$ May 19, 1995

This document was reviewed following the procedures described in WHC-CM-3-4 and is:

APPROVED FOR PUBLIC RELEASE

WHC Information Release Administration Specialist:

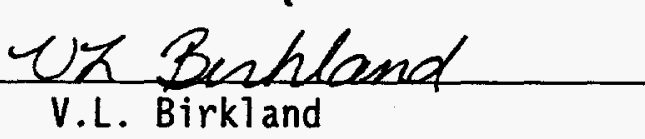

May 19, 1995 
WHC-EP-0856

\section{CONTENTS}

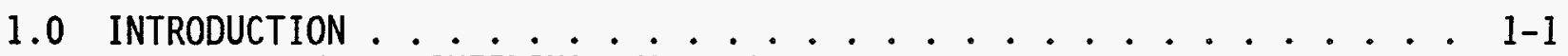

1.1 SYSTEMS ENGINEERING ANALYSIS ............. . . . $1-1$

1.2 PROCESS FLOWSHEET . . . . . . . . . . . . . . . 1-1

1.3 SUMMARY SCHEDULE . . . . . . . . . . . . . . $1-1$

1.4 TANK WASTE REMEDIATION SYSTEM ESTIMATED PROGRAM COST . . . . 1-5

1.5 LOCATION OF FACILITIES . . . . . . . . . . . . 1-5

2.0 OPERATIONAL SCENARIO DESCRIPTION ............... 2-1

2.1 MANAGE TANK WASTE ................. 2-1

2.1.1 Store Waste .............. 2-1

2.1 .2 Characterize Waste ............ 2-5

2.1.3 Transfer Stored Waste ........... 2- 2-

2.1 .4 Concentrate Waste ............. 2-6

2.2 PROCESS WASTE ................. . . 2-8

2.2.1 Retrieve Tank Waste ............ 2-8

2.2.2 Store In-Process Wastes . . . . . . . . . 2-15

2.2.3 Pretreat Tank Waste .......... 2-16

2.2.4 Low-Level Waste Vitrification and Disposal . . . . . 2-22

2.2.5 Immobilize High-Level Waste/Transuranic Waste . . . . 2-24

2.2.6 Prepare Cesium/Strontium Capsules for Disposal . . . . 2-25

2.2.7 Interim Store Immobilized Waste ........ 2-26

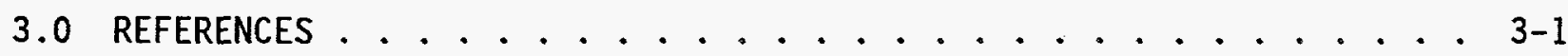


WHC-EP-0856

\section{LIST OF FIGURES}

1-1 TWRS Function Tree ................ 1-2

1-2 TWRS Strategy ................. 1-3

1-3 TWRS Process Flowsheet ................ 1-4

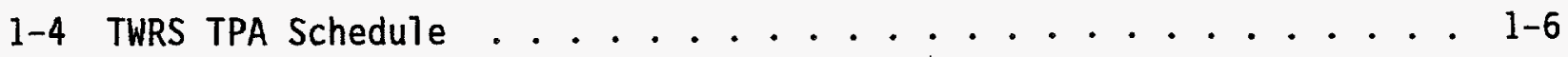

1-5 TWRS Treatment Complex Site Location. . . . . . . . . 1-7

2-1 Manage Tank Waste System Description ... . . . . . . 2-2

2-2 242-A Evaporator . . . . . . . . . . . 2-7

2-3 Process Waste System Description . . . . . . . . 2-9

2-4 Tank Waste Retrieval Sequence ............ 2-11

\section{LIST OF TABLES}

2-1 SST and DST Waste Volume and Waste 0xides ........ 2-13

2-2 Estimated Radionuclides Disposed as LLW from Pretreatment of DST Wastes (1988 DOE Planning Case) .............. 2-20 
WHC-EP-0856

\subsection{INTRODUCTION}

The Tank Waste Remediation System (TWRS) mission is to store, treat, and immobilize highly radioactive Hanford waste (current and future tank waste and the strontium and cesium capsules) in an environmental7y sound, safe, and cost-effective manner (DOE 1993). This operational scenario is a description of the facilities that are necessary to remediate the Hanford Site tank wastes.

The TWRS Program is developing technologies, conducting engineering analyses, and preparing for design and construction of facilities necessary to remediate the Hanford Site tank wastes. An Environmental Impact Statement (EIS) is being prepared to evaluate proposed actions of the TWRS. This operational scenario is only one of many plausible scenarios that would result from the completion of TWRS technology development, engineering analyses, design and construction activities and the TWRS EIS. This operational scenario will be updated as the development of the TWRS proceeds and will be used as a benchmark by which to evaluate alternative scenarios.

\subsection{SYSTEMS ENGINEERING ANALYSIS}

A systems engineering analysis has been conducted to determine the functions and requirements necessary to accomplish the TWRS mission (DOE 1994a). The primary functions identified to conduct the TWRS mission are identified in Figure 1-1. This operational scenario represents a description of the physical system for accomplishing the TWRS mission and is consistent with the defined TWRS functions and requirements. Figure 1-2 depicts a schematic of the major physical system components necessary for accomplishing the TWRS mission. The description of the TWRS operational scenario is structured in terms of the TWRS function identified in Figure 1-1.

\subsection{PROCESS FLOWSHEET}

A process flowsheet has been developed for treatment and disposal of Hanford Site tank wastes (Orme 1994). This flowsheet provides the technical basis for the TWRS operational scenario. A simplified schematic of the TWRS process flowsheet is provided in Figure 1-3.

\subsection{SUMMARY SCHEDULE}

The U.S. Department of Energy (DOE), U.S. Environmental Protection Agency (EPA), and the Washington State Department of Ecology (Ecology) have entered into the Hanford Federal Facility Agreement and Consent Order (Tri-Party Agreement)(Ecology et al. 1994) to:

- Ensure that the environmental impacts associated with past and present activities at the Hanford Site are thoroughly investigated and appropriate response actions are taken as necessary to protect the public health, welfare, and environment. 
WHC-EP-0856

Figure 1-1. TWRS Function Tree.

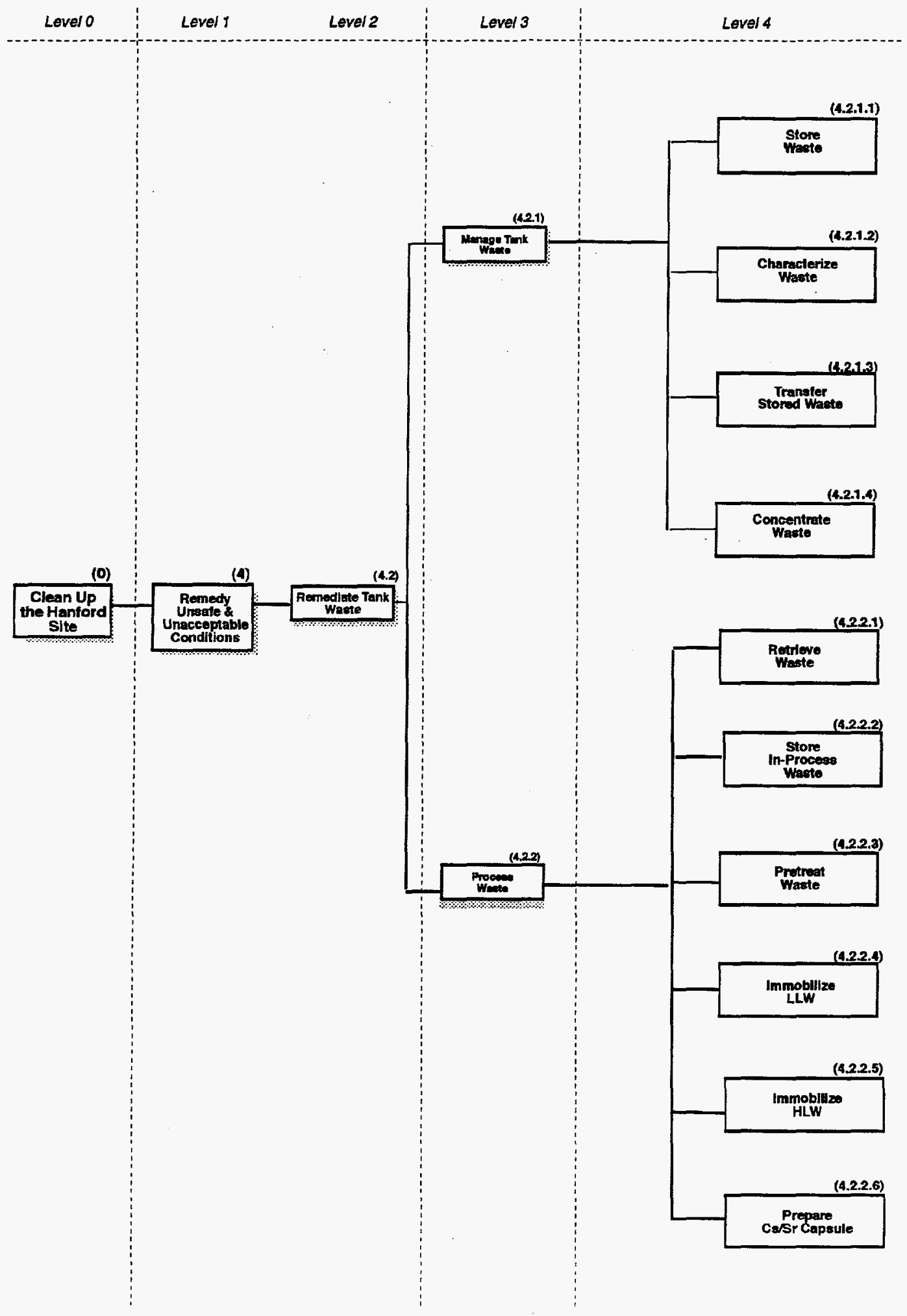


WHC-EP-0856

Figure 1-2. TWRS Strategy.

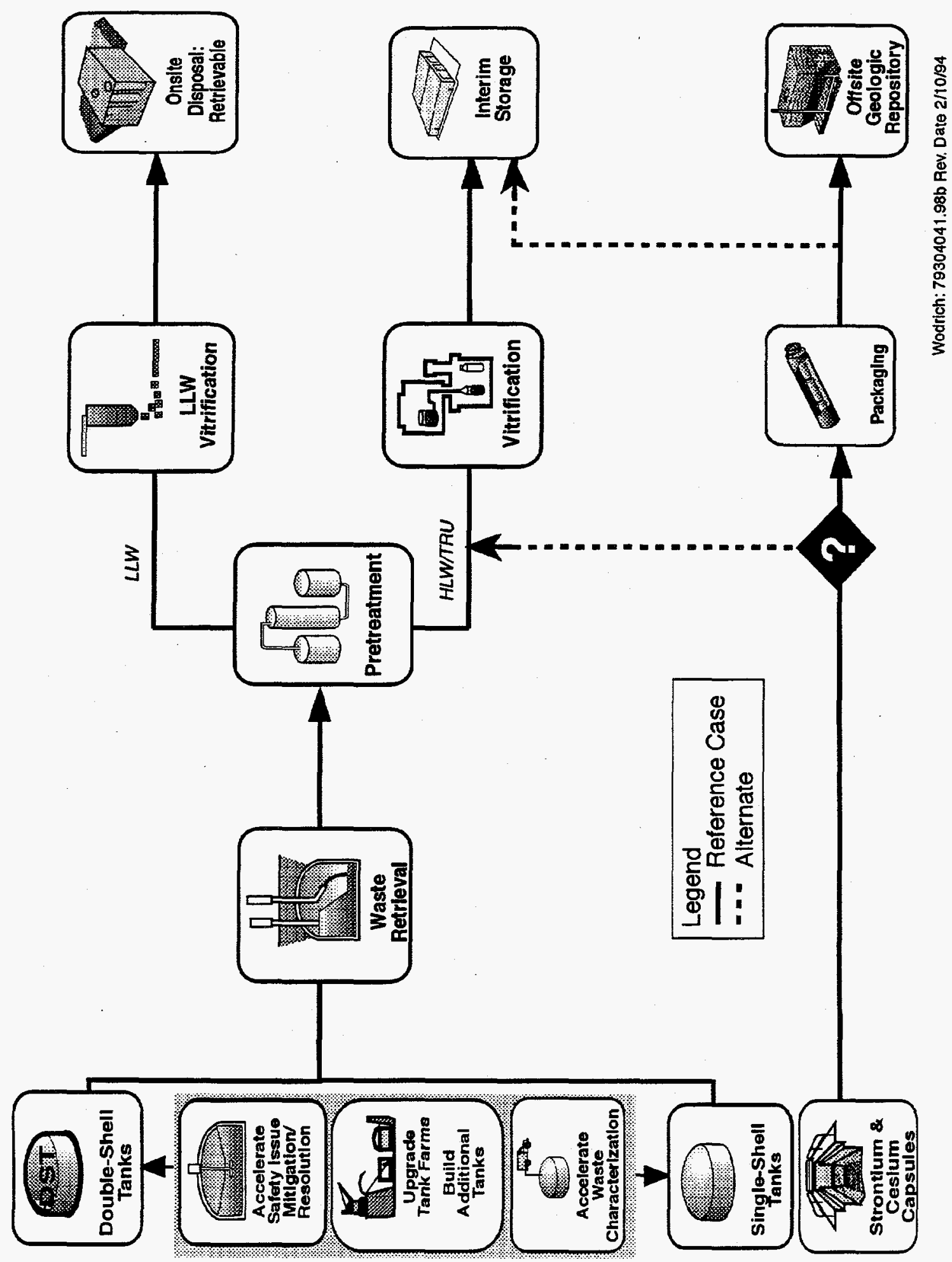


Figure 1-3 TWRS Process Flowsheet
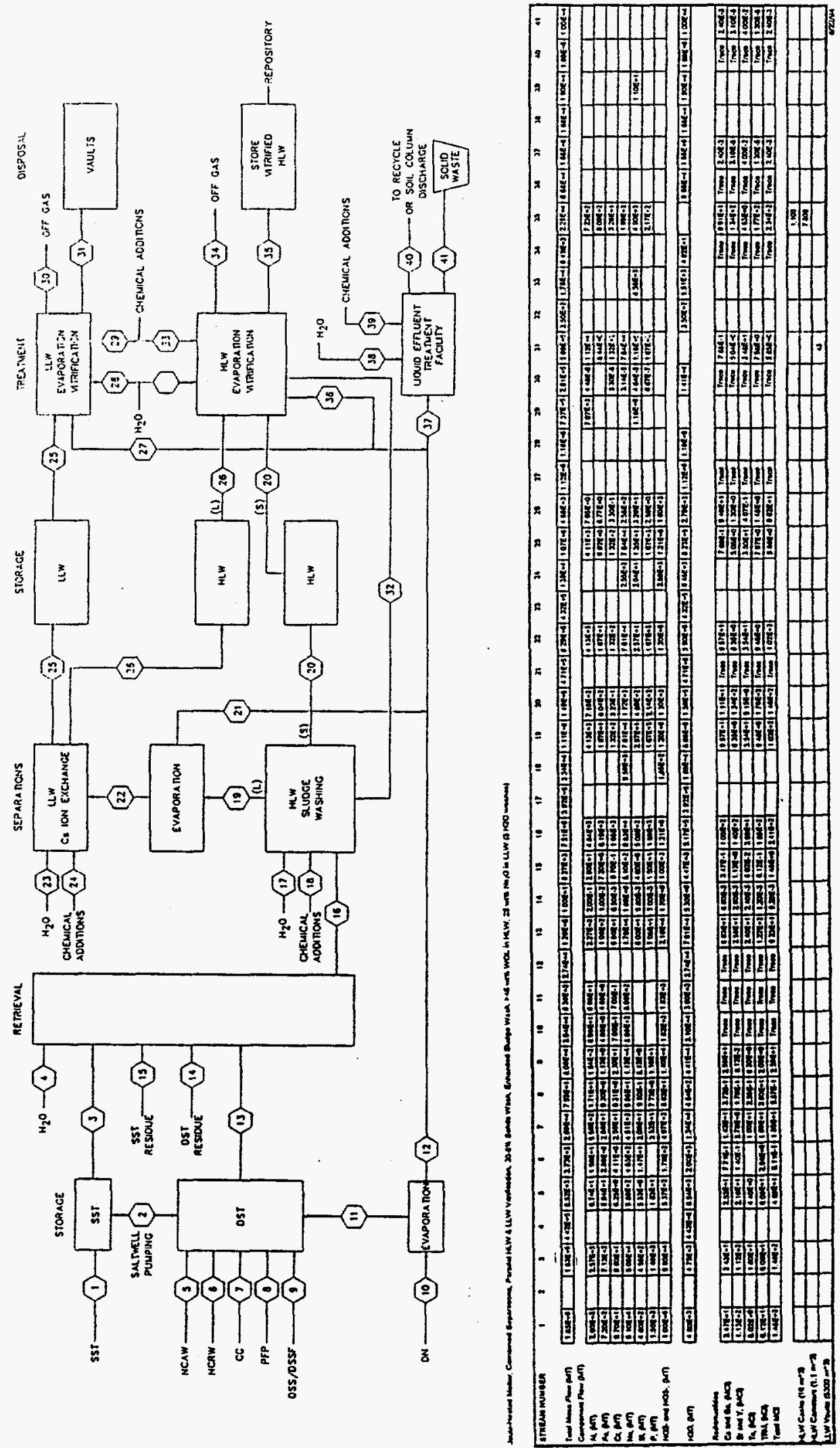
- Provide a framework for permitting treatment, storage, and disposal units.

- Promote orderly, effective investigation and clean up of contamination at the Hanford Site, and avoid litigation between the three parties.

The Tri-Party Agreement establishes a time table (i.e., milestones) for characterizing the Hanford Site tank wastes, resolving tank safety issues, upgrading the underground storage tanks to comply with regulations, resolve safety issues and support waste retrieval, retrieving tank wastes, pretreatment, treatment, and disposal of tank wastes. A simplified schedule depicting the TWRS Tri-Party Agreement milestones is depicted in Figure 1-4.

\subsection{TANK WASTE REMEDIATION SYSTEM ESTIMATED PROGRAM COST}

An estimate of the annual budget required to accomplish the TWRS mission is contained in the Tank Waste Remediation System Multi-Year Work Plan, WHC-SP-1101, Rev. O (WHC 1994C). This operational scenario is consistent with the technical scope and cost estimates used to develop the annual budget contained in the Tank Waste Remediation System Multi-Year Work Plan.

\subsection{LOCATION OF FACILITIES}

Facilities for remediation of tank waste are located in the 200 central plateau area of the Hanford Site. This region is designated as the 200 West and 200 East Areas. In the 200 West Area, there are 83 Single-Shell Tanks (SST) and 3 existing Double-She11 Tanks (DST). The 200 East Area contains 66 SSTs, 25 existing DSTs, and the 242-A Evaporator, along with miscellaneous waste facilities.

Because the bulk of the DSTs are contained within the 200 East Area, waste treatment facilities will be located near these tanks to minimize transport distances and utilize these tanks for interim storage. Waste treatment facilities will be located in the 200 East Area in a region between the existing 200 East Area powerhouse and the Plutonium Uranium Extraction (PUREX) Facility (Augustine 1995). Support facilities will be located to maximize use of the infrastructure constructed for the Hanford Waste Vitrification Plant (now defunct). Figure 1-5 depicts the proposed arrangement of the TWRS treatment complex in relationship to existing tank systems and other proposed projects. 


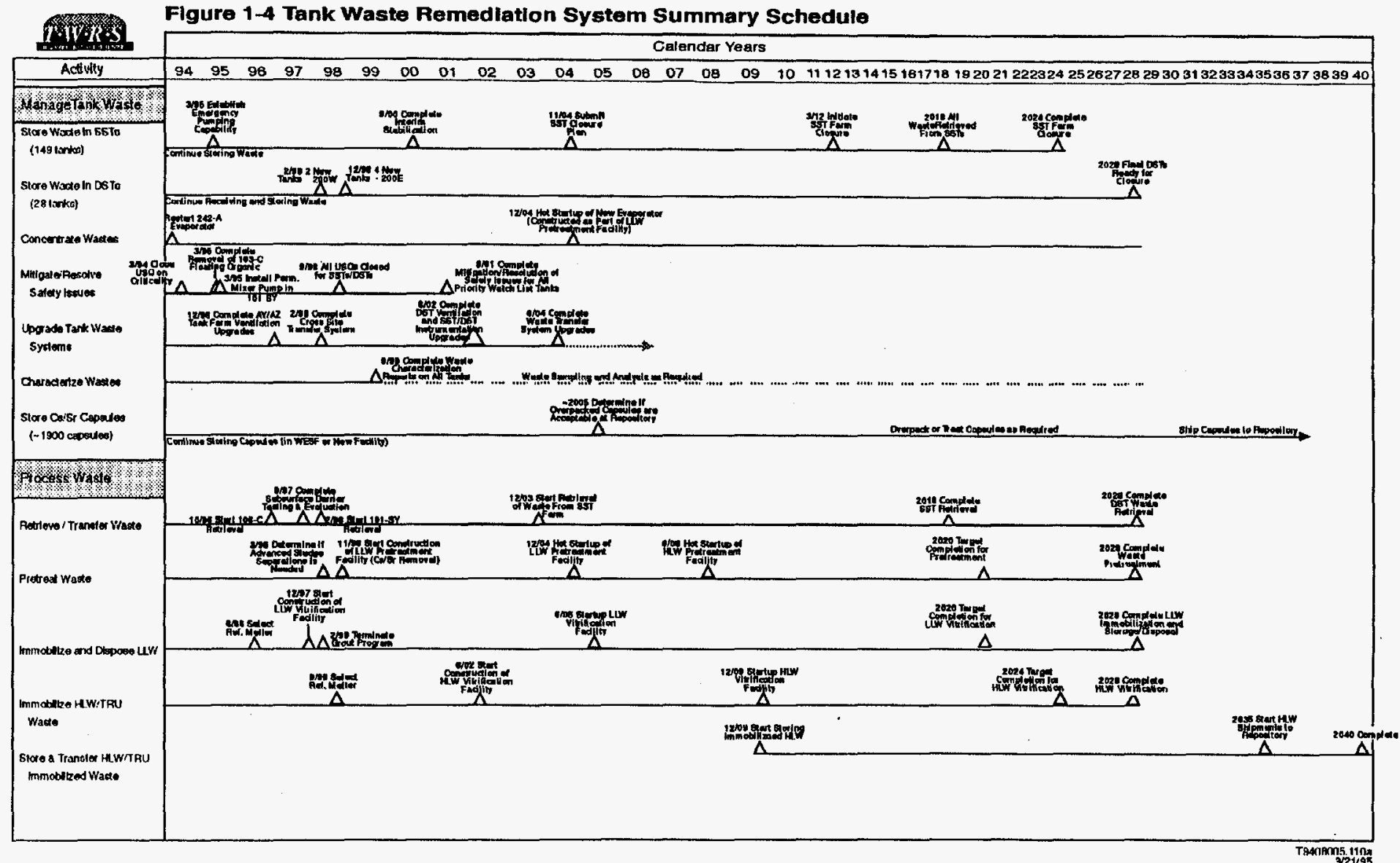


Figure 1-5 TWRS Treatment Complex Site Location

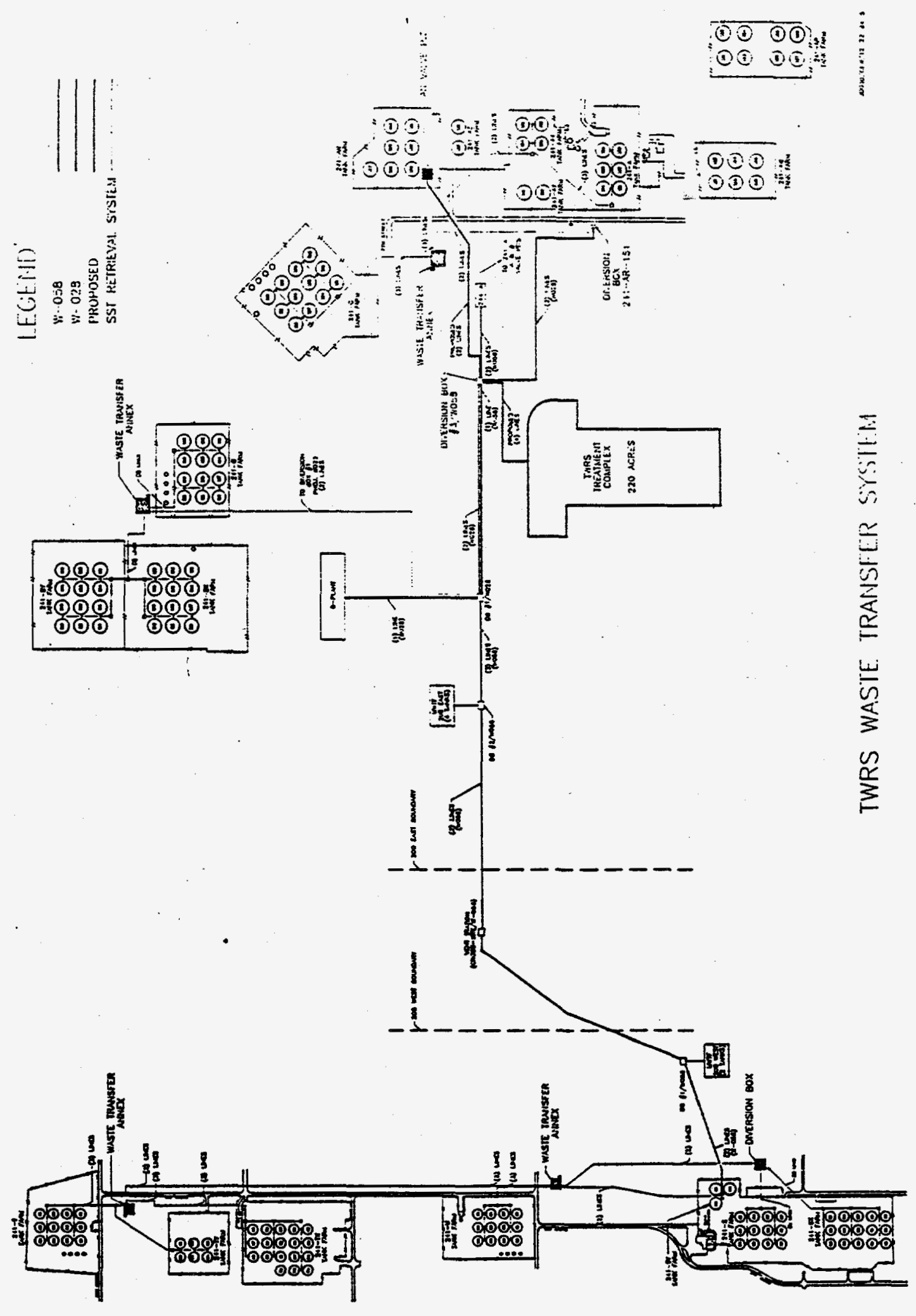


WHC-EP-0856

This page intentionally left blank. 
WHC-EP-0856

\subsection{OPERATIONAL SCENARIO DESCRIPTION}

This operational scenario represents a description of the physical system for accomplishing the TWRS mission and is consistent with the defined TWRS functions and requirements. Where possible, detailed information has been provided, such as the timing of waste retrieval, composition of waste streams, and tank utilization.

\subsection{MANAGE TANK WASTE}

This section describes the principle actions being conducted by the Maintenance \& Operations (M\&O) contractor to safely store tank wastes until retrieved for treatment and disposal. Activities are described that are currently being conducted or planned to resolve safety issues, upgrade the tank farm infrastructure, characterize tank wastes, and manage the available tank space inventory. Figure 2-1 depicts "manage tank waste" activities and interfaces with other Hanford Site systems.

\subsubsection{Store Waste}

There are currently about 220 million liters (59 Mgal) of waste in storage within the SSTs and DSTs (WHC 1994d). Safety issues associated with continued storage of these wastes are to be mitigated and/or resolved. The tank system infrastructure will be upgraded to support safe storage of tank wastes and facilitate retrieval, treatment, and disposal of tank wastes. The currently identified project for upgrading the tank farm infrastructure is Project W-314, Tank Farm Restoration and Safe Operations. The design requirements for Project W-314 are specified in the Tank Farm Restoration and Safe Operations, Design Requirements Document, WHC-SD-W314-DRD-001, Rev. 0, (WHC 1994e).

There are four priority 1 safety issues associated with storage of wastes within the 149 SSTs and 28 DSTs at the Hanford Site requiring resolution. These tank waste safety issues are:

(1) Flammable Gas (i.e., hydrogen)

(2) Ferrocyanide

(3) Reactive Organic Compounds

(4) High-Heat Load

Those tanks identified as potentially exhibiting these safety issues are listed in the Waste Tank Summary report (WHC 1994d). 


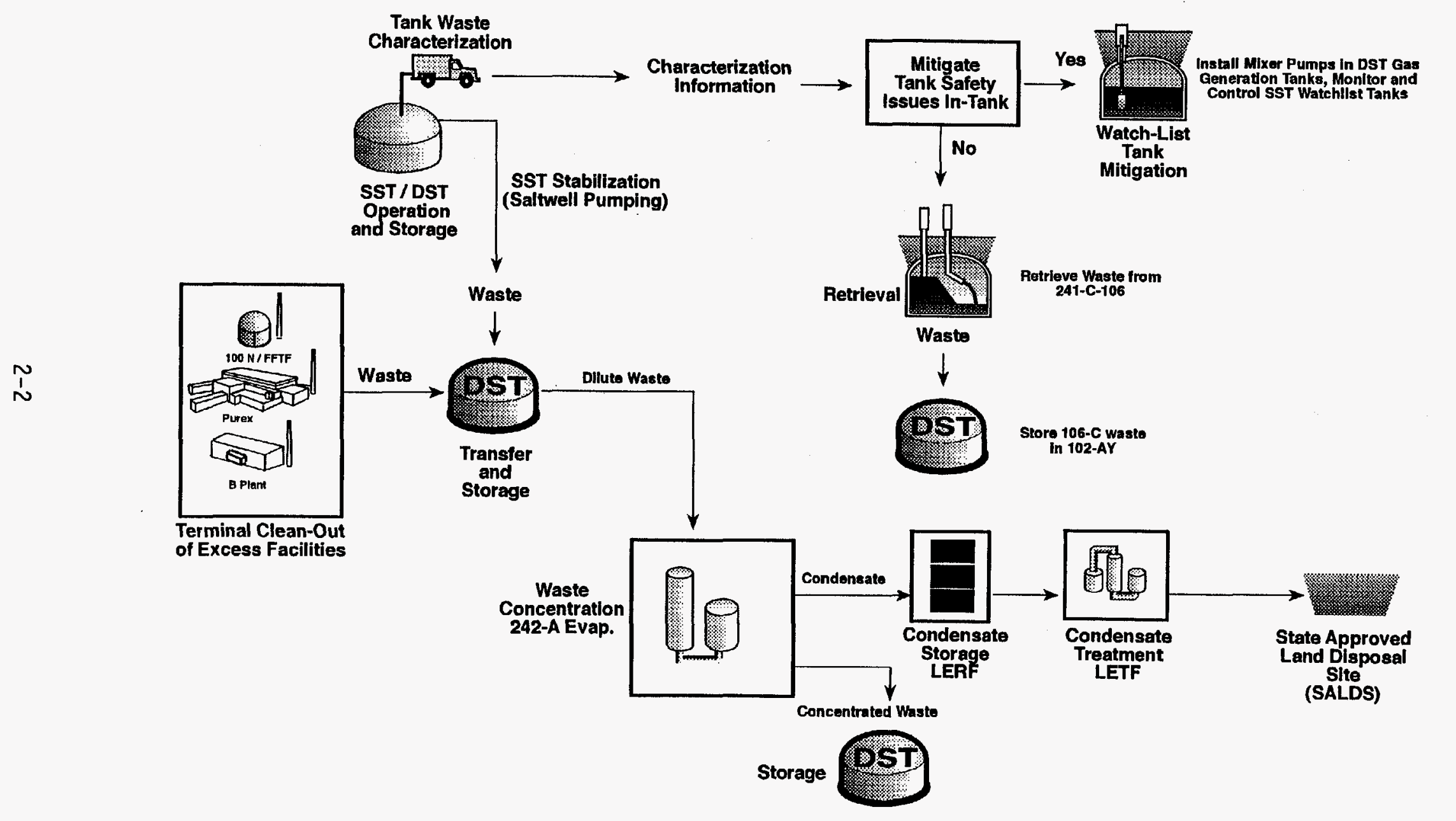


2.1.1.1 Flammable Gas Safety Issue Mitigation. In order to mitigate the episodic generation of $f l$ ammable gases from wastes contained within tank 241-SY-101, a mixer pump was installed during July 1993. This mixer pump has been proven to be reliable for mitigating episodic generation of flammable gas. Evaluation of the flammable gas generating wastes contained in the other DSTs (241-AN-103, 241-AN-104, 241-AN-105, 241-AW-101, 241-SY-103) is being conducted to determine appropriate mitigation actions (WHC 1994c, Section 7.4).

The DOE is evaluating dilution to passively mitigate the episodic generation of flammable gas wastes. An evaluation of dilution requirements for wastes in tanks 241-SY-101 and 241-SY-103, conducted by the Pacific Northwest Laboratory (PNL), indicates a dilution of 1 part waste to 1 parts 2 molar free hydroxide solution may be sufficient to prevent episodic generation of flammable gases (PNL 1994). However, the effectiveness of diluting flammable gas generating wastes to mitigate episodic generation of gases has not been confirmed under laboratory and full-scale testing.

It is presently assumed that mitigation of other flammable gas generating wastes will not be necessary. Hydrogen monitors have been installed in all 25 flammable gas tanks to determine whether these tanks require active mitigation. If necessary, mixer pumps similar in design to the mixer pump that was installed within tank 241-SY-101, will be installed in these tanks (WHC 1994c, pg. 7.4-6). These mixer pumps will circulate wastes within each tank and prevent the accumulation of flammable gases. No additional waste storage capacity is required to mitigate the flammable gas generating wastes (DOE 1995b).

2.1.1.2 Ferrocyanide Safety Issue Resolution. Nickel ferrocyanide was added to wastes and collected in SSTs during 1955 to 1957 to precipitate cesium. In the presence of oxidizing materials such as nitrates and/or nitrites, ferrocyanide compounds can react vigorously, potentially causing an explosion. As such, 24 SSTs were identified on a watch-list as potentially containing sufficient ferrocyanide compounds to support a propagating exothermic reaction. Four ferrocyanide tanks (241-BX-110, 241-BX-111, 241-BY-101, and 241-T-101) were analyzed and determined not capable of supporting a propagating exothermic reaction. These tanks were removed from the ferrocyanide watch-7ist in July 1993 and the associated unreviewed safety question closed in March 1994 (DOE 1994b). Of the remaining twenty ferrocyanide tanks, two (241-BX-102 and 241-BX-106) were removed from the watch-1 ist in early fiscal year (FY) 1995 (WHC 1994c, pg. 7-4.6).

The remaining ferrocyanide watch-1 ist tanks will be analyzed to determine appropriate actions to resolve the safety issue. Recent laboratory work with simulants confirmed the ferrocyanide content decreases over time in intense radiation fields (Lilga et al. 1993 and 1994). Core sampling will be used to confirm aging in tanks projected to have the highest ferrocyanide concentrations and exposed to the lowest radiation field and/or alkali concentrations. It is anticipated that none of the ferrocyanide tanks will require retrieval or pretreatment, but some of the ferrocyanide tanks will require installation of new thermocouple trees and continuous temperature monitoring systems to resolve the safety issue. This equipment will be 
installed by the TWRS Waste Tank Safety Program, as part of the Secretary of Energy's safety initiatives and in accordance with Tri-Party Agreement milestone M-40-02 (Ecology et al. 1994, pg. D-69).

2.1.1.3 Reactive Organic Compounds Issue Resolution. Twenty SSTs have been identified as containing organic chemicals that are potentially flammable and mixtures of organic materials mixed with nitrate and nitrite salts, which could potentially deflagrate. One tank, 241-C-103, contains an organic layer covering the surface of the sludge waste. Westinghouse Hanford Company (WHC) has analyzed the organic layer contained in tank $241-C-103$ and has proposed interim stabilizing this waste. Interstitial liquids will be removed from this tank and transferred to a DST. Additionally, activated carbon filters were installed to resolve a noxious vapor safety issue with this waste.

The reactive organic compound watch-list tanks will be analyzed to determine appropriate actions to resolve the safety issue. It is anticipated that none of these tanks will require retrieval or pretreatment for safe storage, but some of these tanks will require moisture monitoring and control, new thermocouples and pressure monitors. This equipment will be installed by the TWRS Waste Tank Safety Program during FY 1995 through FY 1997 (WHC 1994C, pg. 7-4.4.13).

2.1.1.4 High-Heat Load Issue Resolution. The high heat source waste in tank 241-C-106 is planned to be retrieved beginning in October 1996 to resolve the safety issue associate with continued storage in a SST. Project W-320 will provide the necessary waste retrieval equipment and underground transfer 1 ines to transfer the high-heat waste from tank 241-C-106 into DST 241-AY-102. In addition to resolving the high-heat safety issue, this project will provide a full-scale demonstration of sluicing technology for mobilization of sludge waste. The information gained from conducting sluicing of sludge wastes will be applied to the design of waste retrieval systems for other SSTs (see Section 2.2.1.3).

2.1.1.5 Tank Farm Restoration and Safe Operations Upgrades. Various upgrades to the SSTs and DSTs are being conducted to improve operations, provide instrumentation for monitoring of tank waste conditions (e.g., waste temperature, and 1 iquid level), and mitigate and/or resolve safety issues. Electrical, instrumentation, ventilation, and underground waste transfer pipelines upgrades for SSTs and DSTs will be provided by Project $\mathbf{W}-314$, Tank Farms Restoration and Safe Operations. Project $W-314$ will be conducted in phases, with completion of all upgrades by June 30, 2005 in accordance with Tri-Party Agreement milestone M-43-00 (Ecology et al. 1994, pg. D-77).

Ventilation upgrades to the 241-AY and 241-AZ tank farm were identified prior to the conception of Project $W-314$ and need to be conducted near term. Project $W-030$, AY/AZ Primary Ventilation System Replacement, wi11 provide the necessary modifications to the 241-AY and 241-AZ tank farm ventilation system. Project $W-030$ will be completed by December 31, 1996 in accordance with TriParty Agreement milestone M-43-01 (Ecology et al. 1994, pg. D-78).

2.1.1.6 Additional Double-She11 Tanks. Based upon an assessment of operational risks, flexibility, and future waste generation assumptions, a waste volume projections (WHC 1994f) indicate no additional DST storage capacity is needed to support tank waste management activities through 2004 
(WHC 1995a). Review of waste storage capacity needs will be conducted annually to determine if additional DSTs are needed to support proposed waste processing activities planned for 2005 through 2028. It is anticipated 7 years lead time is necessary to provide new DSTs.

\subsubsection{Characterize Waste}

The physical and chemical characteristics of the different tank wastes are obtained by review of historical processing data, in situ analysis, and/or physical sampling. The tank waste physical and chemical characteristics information is used to resolve safety issues, establish the safety operating basis for the tank farms, determine the 242-A Evaporator operating conditions, design waste retrieval systems, develop and test flowsheets for pretreatment, and HLW and LLW immobilization processes. The strategy and sample schedule are under evaluation to ensure that a technical-based program is implemented that meets program commitments. The current sampling plans include liquid grab samples, vapor samples, push and rotary samples.

\subsubsection{Transfer Stored Waste}

For the next 10 years the TWRS operating mission will be to manage and store tank wastes. This will include mitigating/resolving tank waste safety issues, salt wel1 pumping SSTs, receiving and storing wastes generated during terminal clean out of inactive chemical processing facilities, and waste concentration operations (242-A Evaporator). Wastes contained within the SSTs and DSTs are transferred to DSTs using underground pipelines.

2.1.3.1 Single-Shell Tank Stabilization. Transfer of interstitial waste solutions from SSTs into DSTs (i.e., salt well pumping) is being conducted to reduce the $1 \mathrm{ikelihood}$ and consequences of leaks from these older tanks. At the completion of stabilization, an SST will contain a maximum of 50,000 gal of drainable interstitial 1iquid. AlT SSTs are anticipated to be stabilized by September 30, 2000, in accordance with Tri-Party Agreement milestone M-41-00 (Ecology et al. 1994, pg. D-74).

2.1.3.2 Waste Transfers to Support 242-A Evaporator Operation. Transferring of tank waste to support the 242-A Evaporator operation will be carried out in the A-Farm complex in order to free up tank space to allow retrieval of highheat waste in tank 241-C-106, passive mitigation of flammable gas wastes in tanks 241-SY-101 and 241-SY-103, salt well pumping, or terminal clean out of older facilities such as PUREX and B-PIant. Waste solutions generated from facilities outside the scope of the TWRS (e.g., B Plant, T Plant, PUREX, Waste Sampling and Characterization Facility, and $100 \mathrm{~N}$ Reactor) are received into DSTs either through underground pipelines or the 204-AR Railcar Unloading Facility. Received waste solutions are transferred among DSTs to store waste solutions until processing for disposal is conducted, stage solutions for evaporation using the 242-A Evaporator, and store the concentrated waste solutions.

2.1.3.3 Cross-Site Transfer System/Aging Waste Transfer Lines. A near-term need exists to replace the underground transfer pipelines connecting DSTs in the 200 West Area with the 200 East Area DSTs (i.e., cross-site transfer 
system). The cross-site transfer system is used to transfer waste solutions collected in tank 241-SY-102 to the 200 East Area DSTs. Waste solutions collected in tank 241-SY-102 are generated from salt well pumping, terminal clean out of the Plutonium Finishing Plant (PFP), operation of the 222-S Analytical Laboratory, and operation of the T Plant Decontamination Facility.

The existing cross-site transfer system consists of six transfer lines, four of which are either plugged or suspected of having failed and the remaining two are of questionable integrity. Project $W-058$, Cross-Site Transfer System and Project W-028, Aging Waste Transfer Line, wil1 provide replacement underground transfer Tines for the existing cross-site transfer system. In accordance with Tri-Party Agreement milestone M-43-07, Projects $W-058$ and $W-028$ are anticipated to be completed and operational by February 28, 1998 (Ecology et al. 1994, pg. D-81). The replacement cross-site transfer system/aging waste transfer 1 ines will be used for transfer of the waste from 200 West Area tanks, once space in the 200-E Area DSTs is made available through waste concentration.

The aging waste transfer 7 ines are also planned as the main transfer 1 ine from the DSTs to the planned pretreatment, LLW and HLW vitrification

facilities. New underground pipelines will be provided by a separate project from the tank farms to the diversion boxes provided by Project $W-028$.

\subsubsection{Concentrate Waste}

The 242-A Evaporator - crystallizer is located in the 200 East Area of the Hanford Site. The 242-A Evaporator was constructed in 1976 to be the primary mechanism for reducing the volume of wastes stored within the Hanford Site underground storage tanks. DST 241-AW-102 is the feed tank to the 242-A Evaporator and DST 241-AW-106 is the product receiver tank. Waste solutions are sampled then pump transferred from any of the other 23200 East Area DSTs through a series of underground pipelines and valve boxes to the evaporator feed tank (see Section 2.1.3.2). After evaporation, the concentrated waste solutions are collected into tank 241-AW-106, sampled and transferred to another DST for storage. Process condensates evaporated from tank waste solutions are condensed using a water-supplied heat exchanger, collected into tank TK-C-100, and processed through an ion-exchange column to remove strontium and cesium. A simplified schematic diagram of the 242-A Evaporator is presented in Figure 2-2.

The 242-A Evaporator treated process condensates are collected in the Effluent Retention Facility (ERF). The LERF is designed to hold up to $\sim 13 \mathrm{Mgal}$ of process condensates, with $50 \%$ spare capacity. Process condensates collected in the LERF will be processed through the 200 Area Effluent

Treatment Facility (ETF) for removal of additional radionuclides prior to discharge to the 200 West Area State-Approved Land Disposal Site (SALDS). The LERF, ETF, and TEDF are operated by the Liquid Effluent Management department of the Waste, Analytical, and Environmental Services division and are not part of the TWRS. 


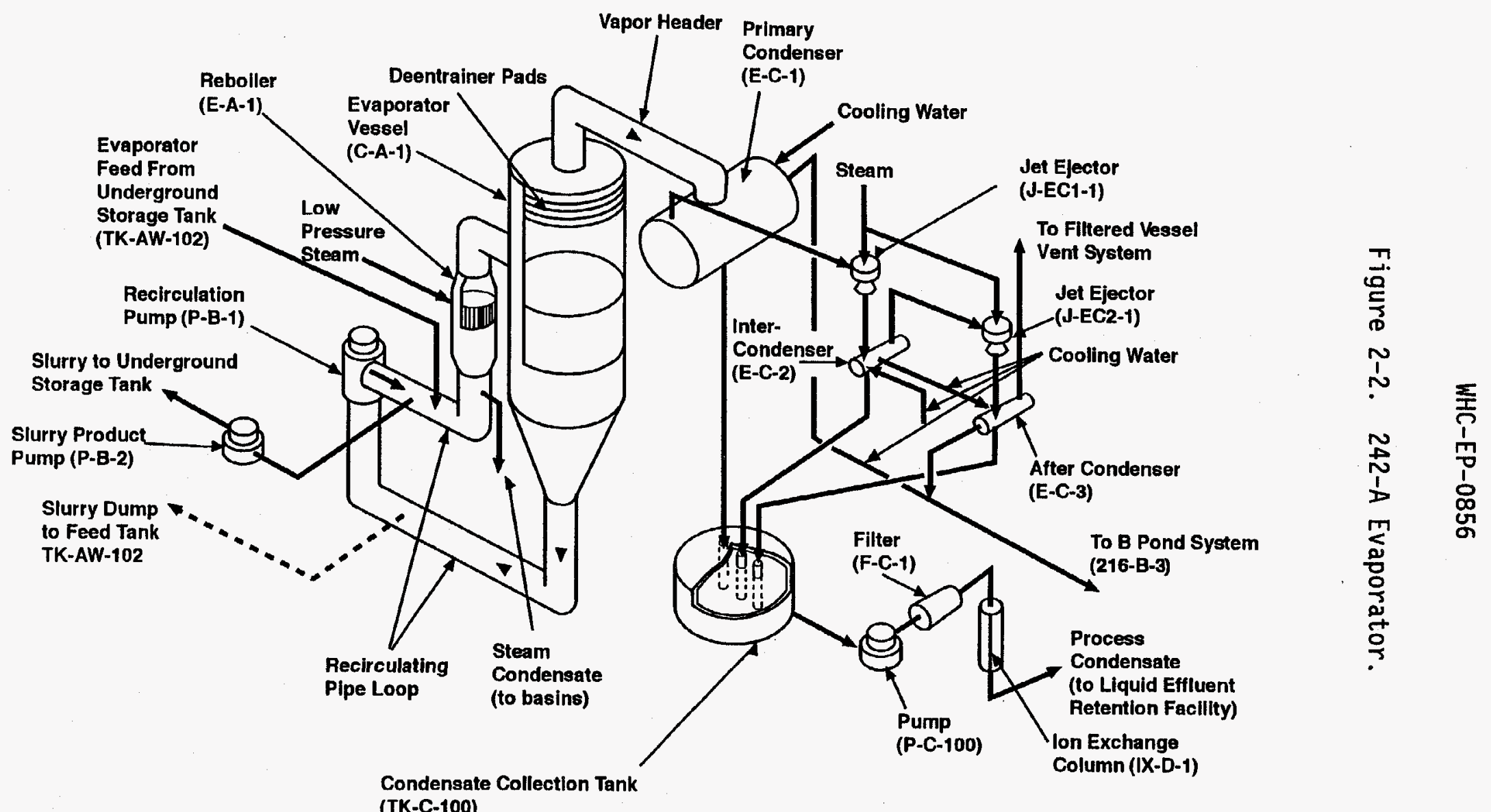


The 242-A Evaporator was restarted in Apri1 1994 and will continue to be operated as necessary to reduce the volume of wastes requiring storage in the DST system. The recent series of upgrades to the 242-A Evaporator

(Project B-534) is projected to extend its service life until 2005. However, additional modifications to the ventilation components of the 242-A Evaporator may be necessary to further extend the service life. Replacement waste evaporation capacity is planned to be included in the scope of the Initial Pretreatment Module, Project W-236B, scheduled for completion by December 2004 (see Pretreat Waste).

\subsection{PROCESS WASTE}

This section describes the principle actions being conducted to retrieve, pretreat, treat, and dispose of Hanford Site tank wastes. Figure 2-3 depicts process waste activities and interfaces with other Hanford Site systems. Technologies are being evaluated to accomplish each of these functions. This operational scenario assumes specific technologies for accomplishing these functions. Alternative technologies could be used to accomplish these same functions, but are not described here.

\subsubsection{Retrieve Tank Waste}

There are numerous potential sequences for retrieving waste from Hanford Site SSTs and DSTs. Candidate tank waste retrieval sequences need to reduce environmental and safety risks, minimize the need for construction of additional DSTs (which are costly and require long lead time to construct), and support the operating requirements of both the LLW and HLW processing systems. The tank waste retrieval sequence identified in this operational scenario is one candidate sequence capable of meeting these identified goals. Other tank waste retrieval sequences are continuing to be evaluated by the TWRS Program. The tank waste retrieval sequence specified in this operational scenario retrieves tank wastes at a rate different than specified in the TriParty Agreement (Ecology et a1. 1994, pg. D-89 and D-90).

The waste retrieval rate specified in the Tri-Party Agreement initiates retrieval of waste from about $50 \%$ of the SSTs in a 4-year-period. The waste retrieval sequence and rate specified in this operational scenario retrieves waste at a relatively smooth rate, averaging approximately 10 tanks per year ( $~ 7 \%$ of total per year).

The tank waste retrieval methods and sequence selected directly influence the waste transfer methods. This operational scenario assumes tank wastes will be primarily retrieved as liquids containing solids. Transfer of retrieved tank wastes is assumed to be conducted using underground pipelines to provide radiological shielding and waste containment. 


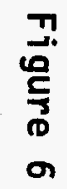

ְ̂

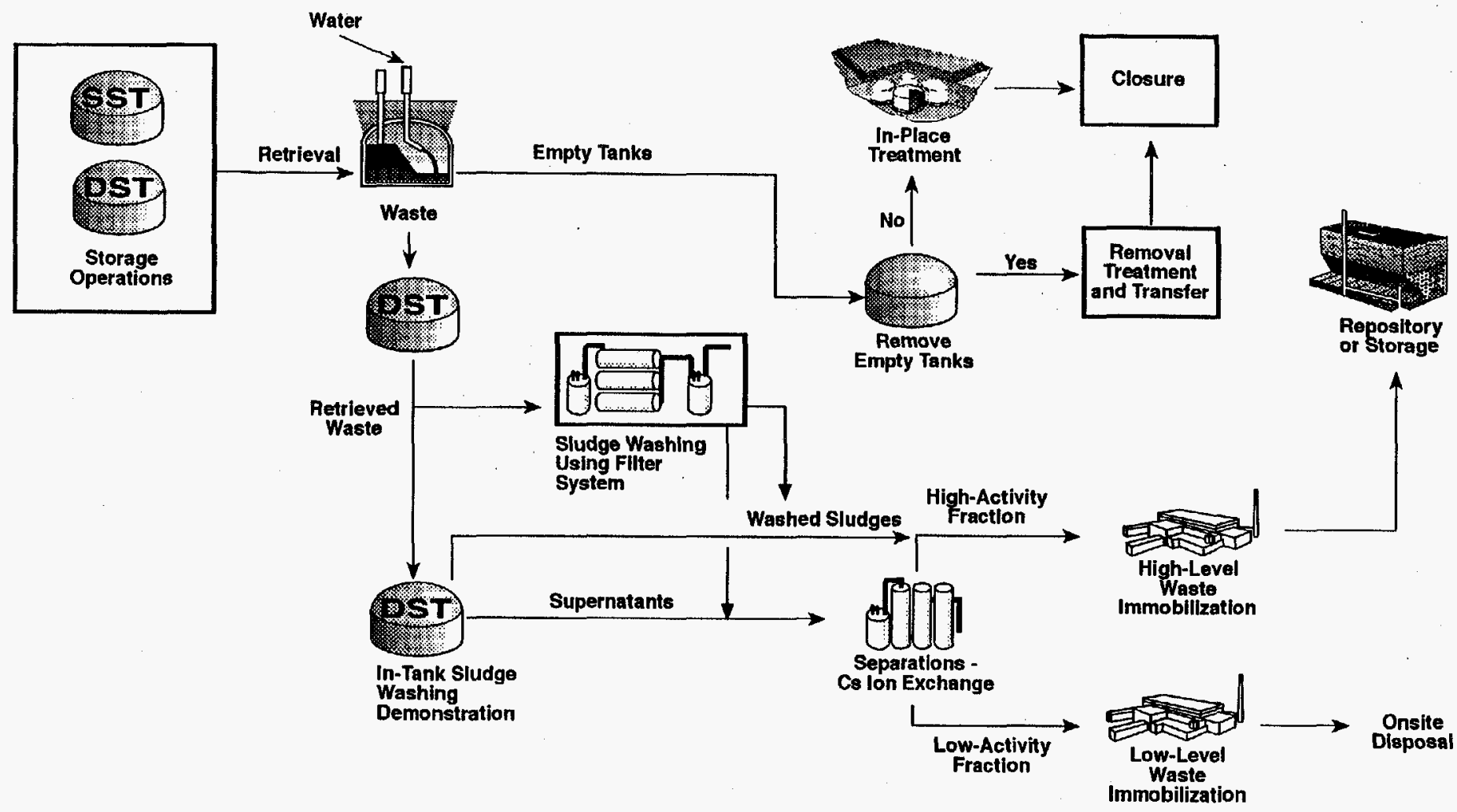

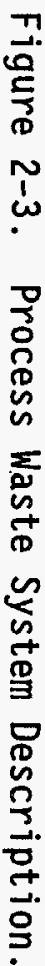

$79401131.1380 \mathrm{ps}$ 05/19/95 
2.2.1.1 Tank Waste Retrieval Sequence. The supernatant pretreatment and LLW vitrification systems require retrieval of tank wastes to provide feed at a relatively constant volumetric flow rate. The LLW does not require blending to reduce the volume of $L L W$ glass. The feed to the pretreatment and $L L W$ vitrification processes is the soluble fraction of tank wastes; supernatants, salt cake and sludge wash solutions. Sodium in the LLW feed has the only identified impact on the volume of the LLW glass. The next highest constituents in the LLW feed; carbonate, nitrite, nitrate, hydroxide, aluminum, and phosphate, are either volatilized in the LLW vitrification process or do not exist in concentrations sufficient to increase the volume of LLW glass. To improve the LLW glass durability, the TWRS Program may have to increase the concentration of aluminum and phosphorous in the LLW glass.

The sludges/solids pretreatment and HLW vitrification systems require retrieval of tank wastes in a manner to support blending for optimum waste loading in the HLW glass. The tank waste species with the largest impact on HLW glass volume are aluminum, chromium, iron, phosphate, uranium, and zirconium. The impact of chromium, phosphate, and zirconium can be reduced by process modifications and/or blending. Retrieval of sludges must occur from more than one tank farm at a time to allow waste blending.

The existing 28 DST system is projected to be near maximum capacity by 2003 (WHC 1994f). In order to minimize the need to construct additional DSTs for interim storage of tank wastes, DST supernatant wastes need to be retrieved and processed first.

To meet these process requirements and comply with the Tri-Party Agreement, tank waste retrieval must be conducted using multiple retrieval units, which operate simultaneously in more than one tank farm. Additionally, the start of LLW vitrification precedes the start of HLW vitrification by 4 years. Therefore, the waste retrieval sequence should initially provide supernatant pretreatment and LLW vitrification feed, followed by sludges for HLW processing.

Figure 2-4 shows a possible order of initiation of waste retrieval operations to meet the aforementioned goals. Waste retrieval would occur from two tanks at a time within the group of tank farms connected to a retrieval annex. Waste would be retrieved from a maximum of eight tanks at a time. The waste retrieval completion dates are preliminary because many factors may a]ter retrieval operations. The waste retrieval initiation sequence shown in Figure 2-4 (Double-She11 Slurry Feed [DSSF], NCAW supernatant, TX, U, S, SX, $\mathrm{TY}, \mathrm{T}, \mathrm{C}, \mathrm{A}, \mathrm{AX}, \mathrm{B}, \mathrm{BX}, \mathrm{BY}$ farms) allow earlier closure of the three operable units in 200 West Area. Other possible waste retrieval sequences are being evaluated (Certa 1995). 


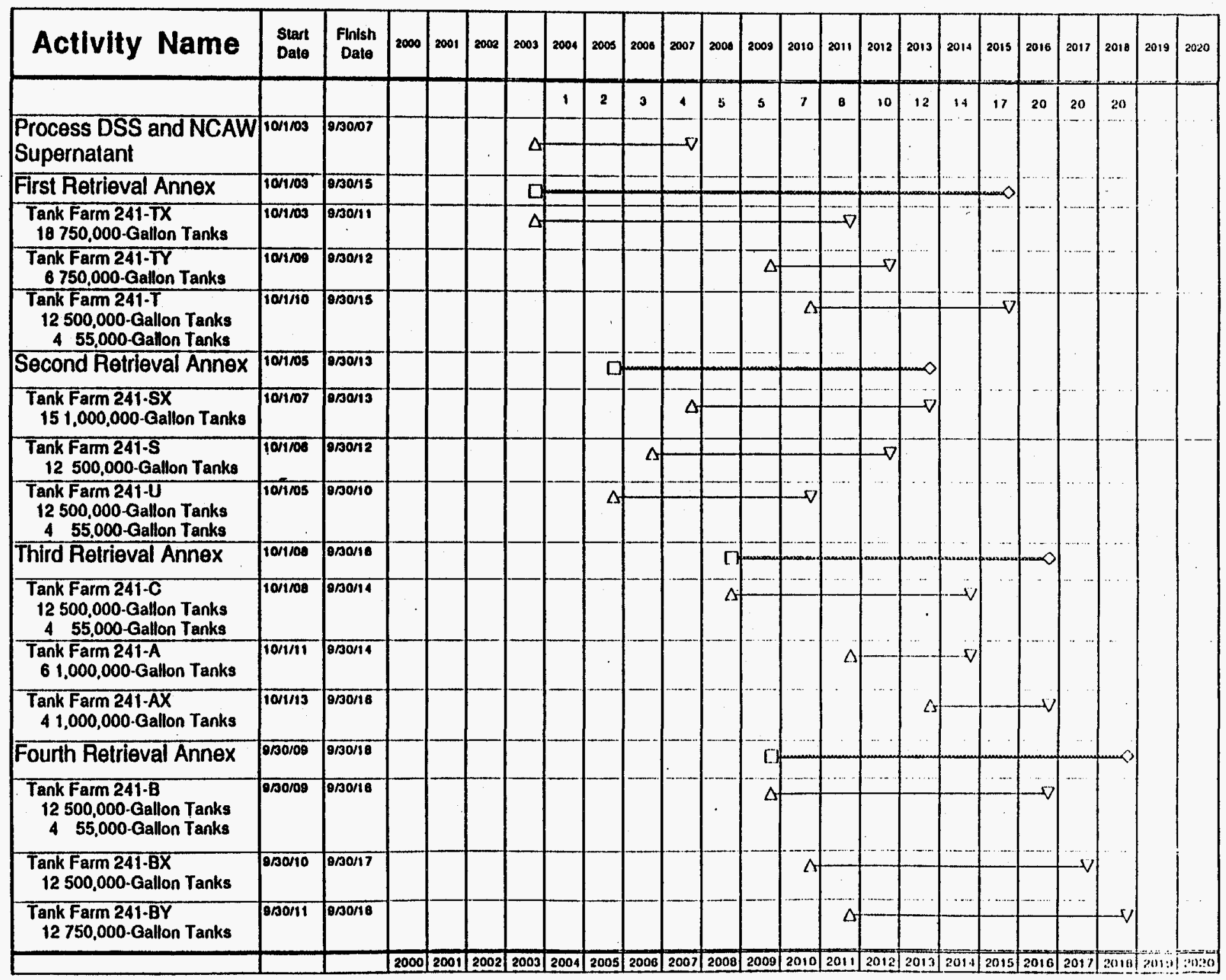


Double-She11 Slurry (DSS), DSSF, and NCAW supernatant will be retrieved beginning in December 2003 for supernatant pretreatment processing. The DSSF/DSS and NCAW supernatant wastes are projected to sustain operations of the supernatant pretreatment and LLW vitrification systems for about 2.5 to 3 years (from year 2004 through 2007).

During the processing of DSS/DSSF and NCAW supernatant, wastes will be retrieved beginning in December 2003 from TX farm, in accordance with TriParty Agreement milestone M-45-05-T01 (Ecology et al. 1994, pg. D-89). Sludges/ solids, pretreatment will not need to be initiated until June 2008 to support HLW vitrification start up in December 2009. Therefore, retrieval of waste from a tank farm containing predominately salt cake is necessary to continue supplying feed for supernate pretreatment and LLW vitrification as well as minimize storage of solids awaiting HLW vitrification. The TX farm wastes is proposed as the source of waste for supernatant pretreatment and LLW vitrification because it has few solids and a large inventory of salt cake.

The 200 West Area SSTs contain the majority of the salt cake waste. Between 70 to 80 percent of the LLW vitrification feed exists in the DSTs and the 200 West Area SSTs, as shown in Table 2-1. By deploying the retrieval infrastructure in the 200 West Area first, continuous feed to the LLW vitrification system can be provided. The 200 West Area SST solids have the largest quantity of species requiring blending for HLW vitrification feed. The ability to retrieve these wastes early allows more blending to occur.

The NCAW solids have been selected as the initial waste for HLW pretreatment and vitrification. This DST waste was selected based on extensive work conducted during the 1980's to establish the pretreatment and HLW vitrification parameters. A demonstration mixer pump system, installed in DST 241-AZ-101 (Project W-151) during FY 1997, will be used initially to demonstrate NCAW solids washing in the existing DSTs during FY 1997 - FY 1998. Additional mixer pump systems installed by Project $W-211$ will be used for retrieval and sludge washing of NCAW presently contained in DST 241-AZ-102. The retrieved solids from 241-C-106 and solids recovered during processing of TX farm wastes will be the next source of feed for sludges/solids pretreatment and $H L W$ vitrification.

The disposition of the remaining DST sludges; PFP and NCRW is being evaluated. The NCRW was generated from removing the cladding from spent nuclear fuel. NCRW waste contains transuranic elements and a relatively 1 arge quantity of zirconium. The PFP waste was generated from purification of plutonium solutions and contains transuranic elements as well as a relatively large quantity of chromium. The NCRW and PFP waste, along with similar SST wastes, are being evaluated to determine whether they are classified as HLW or transuranic waste. The classification of these wastes is expected to be established in March 1995 (WHC 1994c, pg. 7.10-3). 
WHC-EP-0856

Table 2-1. SST and DST Waste Volume and Waste Oxides.

\begin{tabular}{|c|c|c|c|c|}
\hline Tank Farm & $\begin{array}{c}\text { Salt Cake and } \\
\text { Supernatant Volume } \\
\left(\mathrm{m}^{3}\right)\end{array}$ & $\begin{array}{c}\text { Sludge } \\
\text { Volume }\left(\mathrm{m}^{3}\right)\end{array}$ & $\begin{array}{c}\text { Low-Level Waste } \\
\text { Oxides (megagrams) }\end{array}$ & $\begin{array}{c}\text { High-Level Waste } \\
\text { Oxides (megagrams) }\end{array}$ \\
\hline $241-\mathrm{A}$ & 3,700 & 2,100 & 4.00 & 0.22 \\
\hline $241-\mathrm{AX}$ & 3,400 & 100 & 2.44 & 0.15 \\
\hline $241-\mathrm{B}$ & 1,400 & 6,400 & 4.70 & 0.58 \\
\hline $241-\mathrm{BX}$ & 700 & 5,100 & 4.70 & 0.96 \\
\hline $241-\mathrm{BY}$ & 15,200 & 2,700 & 14.60 & 1.41 \\
\hline $241-\mathrm{C}$ & 700 & 7,400 & 6.00 & 1.45 \\
\hline $241-\mathrm{S}$ & 16,400 & 4,400 & 17.30 & 0.86 \\
\hline $241-\mathrm{SX}$ & 12,000 & 4,700 & 14.50 & 1.08 \\
\hline $241-\mathrm{T}$ & 200 & 7,500 & 3.54 & 0.66 \\
\hline $241-\mathrm{TX}$ & 25,600 & 900 & 23.30 & 1.07 \\
\hline $241-\mathrm{TY}$ & 300 & 2,200 & 1.47 & 0.23 \\
\hline $241-\mathrm{U}$ & 11,000 & 2,400 & 9.20 & 0.63 \\
\hline DSTS & 81,400 & 7,400 & 20.80 & 1.76 \\
\hline TOTAL & 171,900 & 53,300 & 126.55 & 11.06 \\
\hline
\end{tabular}

If classified as HLW, the NCRW and PFP waste will be pretreated and blended with SST solids to achieve maximum waste loading in HLW glass. If classified as transuranic waste, the NCRW and PFP waste will be blended with any SST wastes classified as transuranic waste and vitrified for disposal at the transuranic waste repository. This operational scenario assumes the NCRW, PFP, and all SST wastes are classified as HLW.

2.2.1.1 Double-She11 Tank Supernatant Waste Retrieval. The goals for DST waste retrieval have not been specifically defined, but include retrieval of sufficient tank waste for closure of these Resource Conservation and Recovery Act of 1976 (RCRA) facilities. The Hanford Defense Waste Environmental Impact Statement (HDW-EIS) considered a reasonable goal for waste retrieval from DSTs to be $99.95 \%$ removal (DOE 1988). The TWRS EIS will evaluate DST waste retrieval requirements. A DST closure plan defining waste retrieval goals must be developed and accepted by Ecology. Because all tank waste processing is to be completed by December 2028 (Tri-Party Agreement milestones M-50, M-51 and $M-60)$, waste must be retrieved from a 71 the DSTs before this date. The completion date established for SST waste retrieval; September 2018, and the desire to minimize the number of new DSTs required for interim storage of tank wastes will actually result in the completion of DST waste retrieval activities by about 2020 .

Transfer pumps will be installed by the Tank Farm Operations and Maintenance organization in the DSTs that are not currently equipped and the DSS, DSSF, and NCAW supernatants decant transferred to the supernatant pretreatment system. The precipitated aluminum compounds contained in the DSS and DSSF waste tanks will be dissolved by addition of sodium hydroxide solution and processed along with the supernatant fraction. Section 2.2.3 provides further details concerning pretreatment processing of tank wastes. 
Project W-211 will instal1 mixer and transfer pumps for mobilization and transfer of complex concentrate (CC) waste for pretreatment processing. Retrieval of the CC wastes, currently contained in tanks 241-SY-101, 241-SY-103, 241-AN-102, and 241-AN-107, will be conducted during the processing of SST wastes. The specific time for retrieval of the CC waste is not specified because the pretreatment process has not been selected, but these wastes are likely to be processed later in the campaign sequence to permit pretreatment process development, if needed.

2.2.1.2 Double-She11 Tank Sludge Waste Retrieval. Following retrieval and processing of DSS, DSSF, and NCAW supernatants, retrieval of SST salt cake wastes is planned for the second supernatant pretreatment campaign. Retrieval of sludges from DSTs (i.e., NCRW, PFP, and NCAW solids) will be conducted following the initiation of SST salt cake waste retrieval and in parallel with SST salt cake/sludge waste retrieval. DST sludge waste retrieval is not anticipated to begin unti] June 2008 in support of HLW pretreatment and vitrification. DST sludge retrieval will be conducted using mixer and transfer pumps provided by Project $W-211$.

Sludges requiring pretreatment will be mobilized using mixer pumps and transferred to the sludges/solids pretreatment process through underground transfer lines. Following pretreatment, solids are transferred to DSTs for interim storage, again using underground transfer lines. Pretreated sludges will be retrieved from interim storage (i.e., mobilized) using mixer pumps and transferred to the HLW vitrification process, again through underground transfer lines.

2.2.1.3 Single-Shell Tank Salt Cake and Solids Waste Retrieval. The goals for retrieval of waste from SSTs are: (1) remove $99 \%$ of the tank waste or the maximum quantity possible based on the best demonstrated technologies available, and (2) complete waste retrieval activities by September 2018 (Tri-Party Agreement milestone M-45-00). The principle waste retrieval technology to be used is sluicing (i.e., hydraulic). Alternative technologies such as mechanical arm-based systems will be explored for possible application. Technological concepts are being solicited from Universities in FY 1995 and will be evaluated for application during FY 1996.

Application of an arm-based or other alternative waste retrieval system is planned for deployment in tank 241-C-106 by June 2003 (Tri-Party Agreement milestone M-45-03-T02), if required to achieve the waste retrieval goal as previously specified. Waste retrieval from the remaining 148 SSTs is planned to begin in December 2003 (Tri-Party Agreement milestone M-45-05-T01) using sluicing and selective application of arm-based or alternative systems.

2.2.1.4 Single-She11 Tank Farm Retrieval Annexes. Retrieved SST wastes will be collected within an annex facility associated with a group of SST farms. Current plans are to construct in the vicinity of the SST farms two annex facilities in the 200 West Area and two in the 200 East Area. Underground waste transfer pipelines will be constructed to transfer waste from the serviced SSTs to an annex, from the annex facility back to the serviced SSTs, and from the annex to DSTs. These annex facilities are planned to be comprised of three to four 50,000 gal tanks provided with secondary containment systems. A sub-project within Project W-314 is designated as 
providing the waste retrieval annexes and underground pipelines connecting the annexes to both the SST and DST systems.

Waste retrieval solution is supplied from the annex facility to the sluicing systems operating in a serviced SST farm. The retrieved tank waste is pump transferred from a SST to a receiver tank in the annex facility. Typically, the retrieved tank waste solution is very dilute and requires concentration prior to interim storage or pretreatment processing. Concentration of the retrieved tank waste solution is accomplished by decanting and re-using solution to continue waste sluicing. This method of concentrating the retrieved tank waste solution was historically used for sluicing SSTs and serves to minimize the volume of solutions requiring treatment and disposal.

After concentrating, the retrieved tank waste solutions are pump transferred from the retrieval annex facilities to DSTs for interim storage. Waste retrieved from SSTs in the 200 West Area are collected in the SY DST farm (or if constructed the new 200 West Area tanks provided by Project $W-236 \mathrm{~A}$ ) for interim storage and then transferred through the cross-site transfer system/aging waste transfer lines (Projects $W-028$ and $W-058$ ) to the AN DST farm for queuing to pretreatment. Waste retrieved from SSTs in the 200 East Area are collected in the AN DST farm for queuing to pretreatment.

\subsubsection{Store In-Process Wastes}

The "store in-process wastes" function provides interim storage for retrieved tank wastes and the pretreated HLW fraction. Current plans are to operate the LLW vitrification and supernatant pretreatment processes as close coupled processes. Therefore, interim storage of the pretreated LLW fraction will normally not be required. Existing DSTs will be used to provide interim storage of retrieved tank wastes and the pretreated HLW fraction.

A dynamic simulation of the operational scenario described in this document was conducted by Mr. R. Whitman of WHC to determine DST utilization (E/B-SD-W236B-RPT-016, Appendix D). This dynamic simulation indicates the existing 28 DSTs provide sufficient storage capacity to support the retrieval, pretreatment, and treatment of all tank wastes in accordance with the operational scenario described in this document.

Specifically, the dynamic simulation indicates six to eight DSTs are required to accomplish in-tank sludge washing of sludges/solids (E/B-SD-W236BRPT-016, Appendix D) within a 14 year time frame. Three to five DSTs are required for accumulation of washed sludges awaiting HLW vitrification. Four to eight DSTs are required for accumulation of sludge wash solutions awaiting supernatant pretreatment. The range in tank utilization requirements is for contingency. The remaining seven to fifteen existing DSTs are used for receipt of retrieved tank wastes (six tanks) and contingency (one to nine tanks).

If pretreatment of sludges/solids is conducted using filters in a facility as discussed in Section 2.2.3, then only nine to eleven DSTs are needed for accumulation of washed sludges and receipt of retrieved tank wastes. The other existing DSTs can be used for in-tank decomposition of 
organic compounds to precipitate chelated radionuclides, contingency or closed after wastes have been removed.

\subsubsection{Pretreat Tank Waste}

Tank wastes are pretreated to separate into a HLW/transuranic waste fraction and a LLW fraction. The principle process selected to accomplish tank waste pretreatment is the Enhanced Sludge Wash process (Jensen 1994).

The Enhanced Sludge Wash process consists of five operations; (1) alkaline leaching of aluminum, chromium, and phosphate from sludges, (2) water washing of sludges to separate dissolved compounds in the interstitial liquid trapped within the sludges, (3) separation of supernatants from sludges, (4) separation of chelated radionuclides, and (5) separation of radionuclides contained in supernatants. All tank wastes do not need to be processed through all five of these operations. Sludges/solids pretreatment consists of the first four unit operations whereas supernatant pretreatment consists solely of separation of radionuclides contained in supernatants.

The supernatant pretreatment process supports vitrification of LLW and is scheduled to begin operations by December 2004, in accordance with Tri-Party Agreement milestone M-50-02 (Ecology et a1. 1994, pg. D-94). The sludge/solids pretreatment process supports vitrification of HLW and is scheduled to begin ful1-scale operation by June 2008, in accordance with TriParty Agreement milestone M-50-04 (Ecology et al. 1994, pg. D-96).

In order to minimize the need for construction of additional DSTs and support completion of SST waste retrieval by September 2018, the supernatant pretreatment process must process retrieved supernatants and sludge wash solutions as they are generated. According to the reference TWRS process flowsheet, the cesium ion-exchange columns contained in the supernatant pretreatment process will be designed to process a nominally $7 \mathrm{M}$ sodium solution at a time averaged processing rate of approximately 65 liters per minute (17 gpm) (Orme 1994, pg. 33). The maximum sodium molarity of waste solutions processed in the cesium ion-exchange volume is being calculated. The feed solution sodium molarity could be reduced to $5 \mathrm{M}$. Assuming a total operating efficiency of $60 \%$, the instantaneous processing rate is approximately 110 liters per minute $(30 \mathrm{gpm})$. At this processing rate, the pretreatment of al1 Hanford Site tank wastes is anticipated to be completed by December 2018. However, the supernatant pretreatment process would continue to operate for 1 to 2 years longer to process solutions generated from activities to close underground storage tanks and the supernatant pretreatment facility itself. Reducing the sodium molarity of supernatants and sludge wash solutions would necessitate an increase in the supernatant pretreatment facility design processing rate.

Two alternative concepts are being evaluated to accomplish pretreatment of sludges/solids. The first concept uses the existing 3.8 million liter capacity DSTs for conducting pretreatment of sludges/solids. Separation of supernatants from sludges/solids is accomplished by gravitational settling of solids and decantation of supernatants. Separation of chelated radionuclides is accomplished by ensuring the waste solutions contain 3 molar free hydroxide concentration, heating the wastes solutions to approximately 80 to $100^{\circ} \mathrm{C}$, and 
allowing a digestion period of several months to decompose organic compounds. This organic digestion process is still being evaluated along with other processes such as permanganate destruction of organic compounds.

The second concept requires the construction of several smaller capacity tanks and filters for conducting pretreatment of sludges/solids. This sludges/solids pretreatment equipment can be installed in a new stand alone facility or integrated into other facilities planned for processing Hanford Site tank wastes. Caustic leaching and washing of sludges/solids is accomplished using the filters and small vessels. Separation of radionuclides from chelates is accomplished using a low temperature $\left(100\right.$ to $\left.200^{\circ} \mathrm{C}\right)$ hydrothermal or wet air oxidization processes to decompose organic compounds.

An engineering analysis of these two concepts has been conducted by Raytheon/BNFL (Raytheon/BNFL 1994a). The Raytheon/BNFL engineering analys is recommends incorporating the sludges/solids pretreatment process within a facility that also houses the supernatant pretreatment process. A decision to proceed with the out-of-tank approach is anticipated to be forwarded to DOE/RL in April 1995.

WHC has previously recommended construction of a facility that houses equipment for conducting pretreatment of supernatants and vitrification of LLWs (WHC 1994a) based on an engineering assessment of alternative facility concepts (WHC 1994b). In March 1995, DOE declined the WHC recommendation and requested WHC to proceed as follows. Upon contracting with the LLW vitrification architect/engineer (A/E), WHC shal1 structure a process with this $A / E$ and the Initial Pretreatment Module $A / E$ to jointly revisit the facility plant configuration decision.

This operational scenario assumes pretreatment of sludges/solids will be conducted within separate facilities that house equipment for conducting pretreatment of supernatants and vitrification of LLWs. Full-scale demonstration testing within a 3.8 million liter capacity DST (i.e., in-tank sludge wash) will be conducted in parallel to development and testing of filtration equipment for sludges/solids pretreatment. The full scale demonstration of in-tank sludge washing is a contingency process to the filtration process, as well as a means to provide the initial pretreated wastes for the HLW vitrification facility. The in-tank sludge wash demonstration, supernatant pretreatment and sludges/solids pretreatment processes are discussed in greater detail in the following sections.

2.2.3.1 In-tank Sludge Wash Demonstration. In-tank sludge washing will be conducted to demonstrate sludge washing technology, demonstrate sludge mobilization (needed for waste retrieval as well as transfer of pretreated wastes to the HLW vitrification process) and provide the initial source of pretreated HLW for vitrification. This description of the in-tank sludge wash demonstration is based on information provided by G. MacLean (1994) and c. Winkler (1993).

Project W-151, 101-AZ Retrieval Process Test, wi1l install and have operational in October 1996 two mixer pumps within tank 241-AZ-101 to demonstrate mobilization of NCAW sludge (WHC 1994c, pg. F7.7-3). In addition to the two mixer pumps, tank 241-AZ-101 will be equipped with a decanting pump with a floating suction and a transfer pump to conduct a demonstration of in- 
tank sludge washing. The height of the decanting pump floating suction will be regulated with a cable attached to a stepper motor. The pump discharge can be routed back into the tank or through a transfer pipeline to another tank. The discharge line from the decant pump will contain a flow rate transmitter and a turbidity sensor. The transfer pump discharge line will contain pressure and flow rate transmitters. These instruments will be used to determine if entrained solids are present when supernatant is decanted from tank 241-AZ-101, control the transfer rate of solutions, and determine the operating conditions of the pumps. All sensor outputs, valves, and pumps will be controlled by a process control computer (MacLean 1994).

The tank 241-AZ-101 NCAW supernatant contains approximately $2 \mathrm{Ci} \mathrm{Cs}^{137} / 1$ and the sludges contains approximately $29 \mathrm{Ci} \mathrm{Sr} / 7$ (WHC 1993). The supernatant volume is $3,550,000$ liters; sludge volume is approximately 132,500 liters (average sludge depth is $32.3 \mathrm{~cm}$ ), but is not evenly dispersed with in the tank (WHC 1994d). To reduce the radiation dose to workers, the NCAW supernatant will be transferred into tank 241-AY-101 (present contents will be transferred to AP Farm). The NCAW supernatant will be decanted to a height approximately $61 \mathrm{~cm}$ (24 in.) above the sludge level, leaving a heel of about 400,000 liters of supernatant/solids and a decant volume of

$-3,150,000$ 1iters. To provide shielding and the initial sludge wash solution, $-2,800,000$ liters of 241-AY-102 (dilute caustic waste) solution will be added to tank 241-AZ-101 prior to installation of these mixer pumps. After installing the mixer pumps and other equipment, a demonstration of in-tank sludge washing will be conducted during FY 1997.

The NCAW solids are principally iron hydroxide solids that are insoluble in solutions $\mathrm{pH}>3$. NCAW solids do not contain appreciable amounts of aluminum, chrome, or phosphate nor are chelated radionuclides present. Intank sludge washing of NCAW solids will therefore consist only of water washing of sludges to separate dissolved compounds in the interstitial liquid trapped within the sludges and separation of supernatants from sludges. The 241-AY-102 solution added to tank 241-AZ-101 consist of a $0.011 \mathrm{M}$ sodium nitrite and a $0.01 \mathrm{M}$ sodium hydroxide solution to inhibit corrosion of the carbon steel tank. This solution will be used for water washing of the NCAW solids.

Two consecutive water washes (i.e., dilute caustic solution) at a $3: 1$ water to settled solids volume ratio will be conducted to separate dissolved compounds in the interstitial liquid trapped within the NCAW solids (Gibson and Landeene 1987; Wink7er 1993). The dilute caustic solution will be mixed with the NCAW solids using the two mixer pumps. The mixer pumps will be turned off and the solids allowed to settle. The NCAW solids are not anticipated to settle to the same density after washing, but expand to a volume 2.25 times the original volume. The wash solution will be decanted to a height approximately $150 \mathrm{~cm}$ (59 in.) above the sludge level, leaving a heel of about 600,000 liters of supernatant and solids. The wash supernatant, $\sim 1,800,000$ liters, will be decanted to another DST for storage prior to evaporation in the 242-A Evaporator. The sodium, hydroxide, and nitrite concentrations of the decanted supernatant are projected to be $0.84,0.19$, and $0.08 \mathrm{M}$, respectively (Place 1991). 
A second washing of the NCAW solids will be conducted by adding 1,800,000 liters of dilute caustic solution to tank 241-AZ-101 and the process repeated. The wash solution will be decanted to a height approximately $150 \mathrm{~cm}$ (59 in.) above the sludge level, leaving a heel of about 600,000 liters of supernatant and solids. The wash supernatant, 1,800,000 1iters, wi11 be decanted to another DST for storage prior to evaporation in the 242-A Evaporator. The sodium, hydroxide, and nitrite concentrations of the decanted supernatant are projected to be $\sim 0.23,0.06$, and $0.03 \mathrm{M}$, respectively (Place 1991). The wash and settling duration is estimated to 102 days (MacLean 1994).

The decanted supernatant solutions from washing tank 241-AZ-101 NCAW solids will be concentrated using the 242-A Evaporator to $7 \mathrm{M}$ sodium solution, reducing the supernatant volume from $3,600,000$ to 275,000 liters. The concentrated wash solution will be transferred to tank 241-AY-101 and combined with the NCAW supernatant resulting in a total volume of 3,150,000 liters.

WHC is evaluating conducting additional in-tank sludge washing of the tank 241-AZ-102 NCAW solids and the tank 241-C-106 solids once retrieved into tank 241-AY-102. This evaluation will consider the results from in-tank washing 241-AZ-101 solids, additional equipment needs, timing to provide washed solids for HLW vitrification, as well as results from evaluating filtration methods for conducting enhanced sludge washing. If additional intank sludge washing is pursued, Project $W-211$, Initial DST Retrieval System, will install mixer pumps in the appropriate tanks. This operational scenario assumes that in-tank sludge washing of solids retrieved from tank 241-C-106 and NCAW solids/sludges in tank 241-AZ-102.

2.2.3.2 Supernatant Pretreatment. The U.S. Nuclear Regulatory Commission (NRC) has evaluated the DOE proposed plans for treatment and disposal of Hanford Site tank wastes. The NRC determined for DST wastes "... it would regard the residual fraction as incidental waste, based on the Commission's understanding that DOE will assure that the waste: (1) has been processed (or will be further processed) to remove key radionuclides to the maximum extent that is technically and economically practical; (2) will be incorporated in a solid physical form at a concentration that does not exceed the applicable concentration limits for Class C LLW as set out in 10 CFR Part 61 ; and (3) will be managed, pursuant to the Atomic Energy Act, so that safety requirements comparable to the performance objectives set out in 10 CFR Part 61 are satisfied." (Bernero 1993). The NRC did not evaluate treatment and disposal plans for SST wastes, because DOE has not completed characterization nor an EIS for these wastes.

The specific DOE proposal the NRC evaluated was formulated in 1988 and consisted of cesium removal from NCAW and CC waste supernatants, and transuranic elements removal from NCRW, PFP, NCAW solids, and CC waste. The strontium present in CC waste would not be removed. Removal of technetium was determined not to be practical or cost effective (Rizzo 1989). The quantity of radionuclides routed to LLW treatment and disposal from processing DST wastes was estimated to be $2 \%$ to $3 \%$ of the total original inventory generated from reprocessing spent nuclear fuel. Based on DOE's $1988 \mathrm{plan}$, Table 2-2 identifies the estimated quantity of radionuclides disposed as LLW from pretreatment of DST wastes. 
Table 2-2. Estimated Radionuclides Disposed as LLW from Pretreatment of DST Wastes (1988 DOE Planning Case).

\begin{tabular}{|c|c|}
\hline Radionuclide & Millions of curies \\
\hline$C-14$ & 0.0027 \\
\hline$T c-99$ & 0.016 to 0.028 \\
\hline$I-129$ & $33 \mathrm{E}-06$ \\
\hline Sr-90* & 1 to 8 \\
\hline Cs-137 & 6 to $7^{* *}$ \\
\hline TRU & 0.002 to 0.01 \\
\hline
\end{tabular}

*Decay Corrected to $12 / 1995$

** Could be as much as $14 \mathrm{MC} i$ due to inventory uncertainty

In 1994, the DOE again revised plans for treatment and disposal of Hanford Site tank wastes to include separation of cesium from DSS and DSSF wastes (ion-exchange process) and separation of strontium from CC wastes (complexant destruction and/or precipitation processes). The projected inventory of ${ }^{137} \mathrm{Cs}$ and ${ }^{90} \mathrm{Sr}$ disposed as LLW from processing of DST wastes would be reduced by approximately 6 and $1.9 \mathrm{MCi}$, respectively. Additionally, the DOE proposed processing all SST waste to separate cesium from soluble fractions prior to disposal of the soluble fraction as LLW and disposal of the cesium and insoluble fraction (i.e., sludges/solids) as HLW. The pretreatment of SST wastes would be conducted in a manner similar to DST wastes, with the intent to meet the NRC incidental waste criteria.

Based on the DOE's revised plans for treatment and disposal of Hanford Site tank wastes, the principle radionuclide requiring separation from supernatant solutions is ${ }^{137} \mathrm{Cs}$. A preliminary assessment of the LLW disposal system environmental performance indicates separation of other radionuclides (e.g., technetium) is not expected to be necessary. Cesium is planned to be separated from tank waste supernatants using an ion-exchange process. In accordance with the NRC's incidental waste criteria, separation of strontium and transuranic elements from the soluble portion of CC wastes (and other wastes if necessary) is planned to be conducted by destruction of complexing agents followed by separation of solids that contain the strontium and transuranic elements.

The initial waste for cesium separation processing will be DSS, DSSF, and NCAW supernatant followed by TX farm salt cake waste, sludge wash solutions and remaining salt cake wastes. ${ }^{137} \mathrm{Cs}$ will be removed using Duolite $\mathrm{CS}-100$ ion-exchange resin. Other candidate ion-exchange media (e.g., resorcinol formaldehyde resin and crystalline silicotitanate) are being evaluated and would be used if they offer an advantage to the Duolite CS-100 resin. Sufficient ${ }^{137} \mathrm{Cs}$ will be removed from the supernatants and sludge wash solutions to result in the vitrified LLW fraction containing about 2 to $3 \mathrm{Ci} / \mathrm{m}^{3}$ (Orme 1994, pg. 141, stream 437).

The present concept for conducting the cesium ion-exchange process is to use three ion-exchange columns operated in series and a fourth column in a standby or regeneration mode. The lead column would be used to process supernatants, with the two lag columns acting as polishers to remove trace cesium. Once the lead column is loaded and the effluent from the second 
column begins to show losses of cesium, the lead column will be removed from service and a standby column placed in service. The second column will now be used as the lead column, the initial third column as the second column, and the standby column will be the third column in the series. Processing of supernatants will resume through these three columns. The loaded column is eluted using 0.5 molar nitric acid solution to remove cesium. The cesium eluent is evaporated to recover nitric acid for re-use. The concentrated cesium nitrate solution is adjusted to $\mathrm{pH} 12$ and transferred to a DST for interim storage awaiting HLW vitrification. The eluted column is regenerated using sodium hydroxide solutions and water, then placed in standby until needed. This carousel arrangement of four columns is repeated for processing of all supernatants. The ion-exchange columns, cesium eluate evaporator, and a11 support equipment are sized to process 110 1iters of supernatant per minute, at $60 \%$ total operating efficiency.

The estimated volume of DSS, DSSF, and NCAW supernatant, about 50 million liters, will take about 2.25 years to process through the cesium ion-exchange system at 110 liters per minute and $60 \%$ total operating efficiency. Allowing for inefficiencies relating to start up of a new facility, and processing of DSS/DSSF sludge wash solutions, the processing of DSS, DSSF, and NCAW supernatant is scheduled for December 2004 through December 2007 . Following the processing of DSS, DSSF, and NCAW supernatants, retrieved salt cake waste and sludge wash solutions will be processed in a similar manner, with salt cake waste initially being retrieved from TX farm.

Technologies for the separation of strontium and transuranic elements from the soluble portion of CC wastes (and other wastes if necessary) are being evaluated. Candidate technologies are being developed by various laboratories and consist of either decomposition of complexing agent, precipitation, adsorption, or ion displacement processes. Raytheon/BNFL has conducted an engineering analysis of candidate technologies (Raytheon/ BNFL 1994b and Raytheon/BNFL 1994c). Selection of a reference technology is planned during FY 1995 to support conceptual design only.

2.2.3.3 Sludges/Solids Pretreatment. The goal of sludges/solids pretreatment is to reduce the final volume of $H L W$ resulting from treatment of the Hanford Site tank wastes through separation of nonradioactive components of the waste from insoluble radioactively contaminated sludges/solids. The separation of nonradioactive components; primarily sodium, aluminum, chromium, and phosphate, is achieved by leaching the sludge/solids with caustic and washing the leached sludge/solids with water. Some wastes contain a negligible quantity of caustic soluble components and will only be washed with water to remove interstitial aqueous soluble components. As discussed in Section 2.2.3.1, a demonstration of in-tank pretreatment of sludges/solids will be conducted using the NCAW solids contained in tank 241-AZ-101. However, pretreatment of sludges/solids is assumed to be conducted within a facility that also houses the supernatant pretreatment as discussed in Section 2.2.3.

As compared to processing in existing DSTs, pretreatment of sludges/solids using filters results in less caustic and water wash solutions to dissolve and remove aluminum, chrome, and phosphate compounds. Using less caustic solution reduces the volume of vitrified $L L W$ produced from the wash solutions. By using filters, more efficient separation of dissolved compounds in the interstitial liquid trapped within the sludges can be achieved, thus 
reducing the volume of the vitrified HLW (Raytheon/BNFL 1994a). Pretreatment of sludges/solids in smaller vessels allows caustic leaching to be conducted at elevated temperature, which will enhance dissolution of soluble components.

The initial wastes for sludge/solids pretreatment using filters will consist of the DSS and DSSF. These wastes contain primarily cesium in the supernatant and precipitated aluminum compounds, strontium and transuranic elements in sludges. Approximately 1.3 million liters of sludges and 4.2 million liters of DSS are identified in six (241-AN-103, 241-AN-104, 241-AN-105, 241-AP-105, 241-AW-101, and 241-AW-104) DSTs (WHC 1994d). The sludge volume could be considerably more, because sludge level measurements have not been conducted in three of these tanks (241-AN-105, 241-AP-105, and 241-AW-101) after being filled with DSSF. Additionally, evaporation of existing dilute tank wastes is being conducted to manage tank wastes (see Section 2.1.4) and will generate additional DSSF that could contain sludges.

Before pretreatment of the DSSF/DSS supernatants, these retrieved tank wastes will be filtered to separate suspended solids and avoid pluggage of the cesium ion-exchange column. The solids recovered from filtration of DSSF/DSS will be washed using a 3 molar sodium hydroxide solution to dissolve aluminum compounds (i.e., caustic leaching). Residual solids will be washed with water following caustic leaching to remove dissolved compounds in the interstitial liquid. Both the caustic leach and water wash solutions will be processed to remove cesium using the same ion-exchange system used for supernatant pretreatment. The residual solids will be combined with the washed NCAW solids contained in tank 241-AZ-101 (see Section 2.2.3.1).

During the processing of the DSSF/DSS sludges/solids, retrieval of salt cake wastes from TX and $U$ farms will be ongoing. Sludges/solids entrained with these retrieved salt cake wastes (approximately 920,000 liters of sludge in TX farm and 2,410,000 liters of sludge in $U$ farm) will be the next feed source for sludges/solids pretreatment. Retrieval of TX farm salt cake waste is scheduled to commence by December 31, 2003. However, supernatant pretreatment processing of retrieved TX farm salt cake waste will not be initiated until January 2008. Therefore, sludges/solids pretreatment of TX farm sludges/solids will not be initiated until January 2008 . This is approximately 6 months in advance of Tri-Party Agreement milestone M-50-04 for commencing full-scale operation of sludges/solids pretreatment (Ecology et a1. 1994, pg. D-96). Pretreatment of TX farm and other retrieved sludges/solids is conducted in a similar manner as described for DSS/DSSF sludges/solids and will be conducted at a rate to support HLW vitrification operations as well as minimize the storage capacity needs.

\subsubsection{Low-Level Waste Vitrification and Disposal}

The LLW fraction separated during pretreatment of Hanford Site tank wastes will be vitrified to immobilize radionuclides and other hazardous waste components prior to disposal at the Hanford Site. The LLW will be disposed in a manner that allows for future retrieval for up to 50 years if future conditions warrant. In accordance with Tri-Party Agreement milestone M-60-05, hot operations of the $L L W$ vitrification process is planned to commence in June 2005 (Ecology et a1. 1994, pg. D-98). 
As with the pretreatment processes, the LLW vitrification process capacity is designed to support completion of tank waste retrieval by September 2018, while minimizing the need to construct additional DSTs for interim storage of tank wastes. The facility will actually complete the processing of the low-level tank waste fraction about 2 to 3 years later, allowing for processing of solutions generated during the closure of tanks and shutdown of the pretreatment process. Therefore, vitrification of the low-level tank waste fraction is projected to be completed by December 2021, approximately 7 years ahead of Tri-Party Agreement milestone M-60-00 (Ecology et a1. 1994, pg. D-98).

To support this schedule, the nominal design capacity of the LLW process is 200 metric tons (MT) of glass per day, at a total operating efficiency of $60 \%$, yielding a net production capacity of $120 \mathrm{MT} /$ day (Orme 1994, pg. 35). The LLW vitrification process is assumed to utilize at least two glass melters to provide redundant capacity (100 MT/day for each melter) and avoid shutdown of operations due to melter unavailability.

Evaluation of glass melters capable of providing the necessary capacity is being conducted during FY 1995 through FY 1996, with the intent to select a reference melter(s) and glass formulation by June 1996 in accordance with TriParty Agreement milestone M-60-02 (Ecology et a1. 1994, pg. D-98). Final selection of glass formulation (including matrix material, if any), glass form (monoliths, cullet, gems, etc.), and disposal system configuration will be based on meeting environmental performance requirements established by the DOE, as well as other system performance criteria.

Pending the completion of these evaluations, the reference waste $L L W$ form is a glass cullet in a sulfur polymer cement binder (Orme 1994, pg. 36). The LLW glass will contain nominally 25 wt\% sodium oxide, with the waste form being approximately $70 \%$ glass and $30 \%$ sulfur polymer cement binder on a volume basis. The glass cullet in sulfur polymer cement binder waste form was selected based on the following:

1. The matrix has no permeability, thus isolating the glass and preventing leaching of contaminants,

2. If cracks form in the matrix, the sulfur polymer cement acts as a buffer,

3. Sulfur polymer cement facilitates bulk handling of the $L L W$,

4. Sulfur polymer cement facilitates retrieval of waste form, if future conditions warrant,

5. Sulfur polymer cement facilitates recycle of off-standard LLW for reprocessing.

The LLW disposal configuration is being evaluated by Fluor Daniel Inc. to determine an optimal waste package and disposal configuration (Garfield 1994). This evaluation will be completed during FY 1995. Pending completion of this evaluation, the glass cullet in sulfur polymer cement binder LLW is envisioned to be disposed near surface in $5,300 \mathrm{~m}^{3}$ concrete vaults. Based on processing all tank wastes using the enhanced sludge wash pretreatment process, 
approximately 43 vaults $\left(2.3 E+05 \mathrm{~m}^{3}\right)$ containing this LLW matrix will be produced from vitrification of the LLW fraction (Orme 1994, pg. 19).

The LLW fraction from pretreatment of the DSS, DSSF, and NCAW supernatants will comprise the initial feed for the LLW vitrification process. At a nominal production capacity of $120 \mathrm{MT} /$ day, the LLW fraction from pretreatment of DSS, DSSF, and NCAW supernatant will comprise approximately 2.25 years of production. Allowing for inefficiencies relating to start up of a new facility, these wastes will be processed in about 3 years, from June 2005 through June 2008. Blending of feed solutions for vitrification will not be necessary, because the composition of the LLW fraction is fairly consistent; containing primarily sodium, with potassium, aluminum, and phosphate as the next most abundant cations. The LLW glass resulting from vitrification of pretreated DSS, DSSF, and NCAW supernatant would contain about 25 wt\% sodium oxide, 2 to 3 wt\% potassium oxide, 2 to 3 wt\% aluminum oxide, and $1 \mathrm{wt} \%$ phosphate. Consistent with pretreatment processing, subsequent feed sources for the LLW vitrification process will be the LLW fraction from pretreatment of retrieved salt cake (initially from TX farm) waste and sludge wash solutions.

\subsubsection{Immobilize High-Level Waste/Transuranic Waste}

The HLW/transuranic waste fraction (i.e., solids and cesium solution) separated during pretreatment of Hanford Site tank wastes will be vitrified to immobilize radionuclides and other hazardous waste components prior to disposal at a commercial spent nuclear fuel and DOE HLW repository. The HLW vitrification process will be contained in a facility near the LLW vitrification and pretreatment processes, to utilize the same support facilities (WHC 1994a). In accordance with Tri-Party Agreement milestone M-51-03, hot operations of the HLW vitrification process is planned to commence in December 2009 (Ecology et al. 1994, pg. D-97).

The HLW vitrification process capacity is designed to support completion of tank waste vitrification by December 2028, while minimizing capital and operating costs. An evaluation of the total life-cycle cost for this facility (i.e., capital construction, operating, and decommissioning and decontamination costs) indicate the minimum total life-cycle costs occurs with a 14-year operating period (Ranade 1994). Therefore, the HLW vitrification facility will actually complete the processing of the high-level tank waste fraction by approximately December 2023, approximately 5 years ahead of TriParty Agreement milestone M-51-00 (Ecology et al. 1994, pg. D-97).

To support this scheduTe, the nominal design capacity of the HLW process is 12 MT of glass per day, at a total operating efficiency of $60 \%$, yielding a net production capacity of $\approx 8$ MT/day (Orme 1994, pg. 34). The HLW vitrification process is assumed to utilize at least two glass melters to provide redundant capacity (4 MT/day for each melter) and avoid shutdown of operations due to melter unavailability. If development of the enhanced sludge wash process is unsuccessful and simple sludge washing is used, the design capacity of the HLW vitrification process would need to be increased to 20 MT per day to process the estimated 62,800 MT of washed sludges at 25 wt\% waste oxide Toading. 
Evaluation of glass melters capable of providing the necessary capacity is being conducted during FY 1995 through FY 1998, with the intent to select a reference me1ter(s) and glass formulation by September 1998 in accordance with Tri-Party Agreement milestone M-51-02 (Ecology et a1. 1994, pg. D-97). Final selection of glass formulation, glass form (monoliths, cullet, gems, etc.), and disposal container will be based on meeting the repository waste acceptance requirements established by the DOE and economic considerations (e.g., interim storage costs, repository disposal fee).

The configuration of the HLW disposal container is being evaluated to determine an optimal waste package. This evaluation will be completed during FY 1995. Pending the completion of these evaluations, the reference waste HLW form is a $45 \mathrm{wt} \%$ waste oxide glass monolith contained in a $0.68 \mathrm{~m}$ o.d. by $4.57 \mathrm{~m}$ length ( $1.26 \mathrm{~m}^{3}$ capacity at $90 \%$ fi11) canister (Orme 1994, pg. 35). The $1.26 \mathrm{~m}^{3}$ canister is selected to minimize the repository disposal fee (DOE-RW 1993).

The HLW fraction from pretreatment of the NCAW (both tanks 241-AZ-101 and 241-AZ-102), tank 241-C-106 solids/s7udges, and the DSSF/DSS will comprise the initial feed for the HLW vitrification process. At a nominal production capacity of 8 MT/day, this HLW will comprise approximately 6 months of production. Allowing for inefficiencies relating to start up of a new facility, these wastes will be processed in about 12 months, from December 2009 through December 2010. Blending of these feed solutions for vitrification will not be necessary because the composition of the HLW glass is not limited by any particular component, but instead limited by the total quantity of waste oxides present.

Consistent with pretreatment processing, subsequent feed sources for the HLW vitrification process will be the HLW fraction from pretreatment of retrieved SST and DST sludges/solids and the cesium from the supernatant pretreatment process. Blending of these feed solutions for vitrification will be necessary, to avoid increasing the HLW glass composition due to individual waste component limits. Assuming uniform blending, approximately 6,800 canisters would be produced from vitrification of the HLW fraction of the enhanced sludge wash process (Orme 1994, pg. 19). Other blending scenarios are being evaluated in FY 1995 . Early results suggest only a modest (20\%) increase in the number of canisters may occur (Orme 1995). HLW canisters will be temporarily stored at the Hanford Site until a geological repository is available.

\subsubsection{Prepare Cesium/Strontium Capsules for Disposal}

Encapsulated cesium and strontium isotopic sources are currently stored in the Waste Encapsulation and Storage Facility (WESF) at the Hanford Site. The HWD-EIS record of decision specified the "... encapsulated cesium and strontium wastes will continue to be stored safely until such time as a geologic repository is ready to receive waste for disposal. Prior to shipment to a geologic repository, these wastes will be packaged in accordance with repository waste acceptance specifications." (DOE 1988). 
An evaluation is being conducted to determine if the cesium and strontium capsules with appropriate overpacking comply with the geological waste acceptance specifications (DOE 1994C). Because the capsules contain halides, there is concern that adjacent waste containers may be susceptible to corrosion. This evaluation is anticipated to be complete by August 1995 (WHC 1994g, pg. 4-48). Pending completion of this evaluation, it is assumed the cesium and strontium capsules can be packaged to meet geological waste acceptance specifications. The TWRS Program will receive the cesium and strontium capsules from the WESF and package these wastes in accordance with the geological repository waste acceptance specifications.

The HLW vitrification facility will include features supporting the receipt and repackaging of cesium and strontium capsules. When the HLW vitrification facility begins operations in December 2009, overpacking of capsules will also commence. Overpacked capsules will be temporarily stored at the Hanford Site until a geological repository is available to receive this HLW. An estimated 100 to $200(0.68 \mathrm{~m} 0 . \mathrm{d}$. by $4.57 \mathrm{~m}$ length) canisters would be produced from overpacking capsules.

\subsubsection{Interim Store Immobilized Waste}

The spent nuclear fuel/HLW geological repository is scheduled to begin receipt of HLW beginning in 2015 (DOE 1994c, pg. 26). It is anticipated $H L W$ will be initially received from other DOE sites (i.e., West Valley Demonstration Project and Savannah River Site) because these sites will have already completed immobilization operations. Sufficient interim storage capacity for all the HLW canisters and the overpacked cesium and strontium capsules will be provided at the Hanford Site. The canister interim storage facility is envisioned to be a belowgrade concrete structure with lined shafts for interim storage of canisters. Air cooling of the canisters will be provided, as well as an abovegrade building used to house equipment necessary for placement and retrieval of the canisters. 
WHC-EP-0856

\subsection{REFERENCES}

Alumka1, W. T., Executive Vice President and Manager Tank Waste Remediation System, Westinghouse Hanford Company, memorandum number 955011 dated January 13, 1995 to T. R. Sheridan, Acting Program Manager Office of Tank Waste Remediation System, MULTI-FUNCTION WASTE TANK FACILITY - DECISION PAPER.

Augustine, C. A., 1995, TWRS Site Evaluation Report, WHC-SD-WM-SE-021, rev. 0, Westinghouse Hanford Company, Richland, Washington.

Awada11a, N. G., September 1994, Position Paper, Need for Additional Waste Storage Capacity and Recommended Path Forward for Project W-236a, Multi-Function Waste Tank Facility, WHC-SD-W236A-ER-011, rev. 0, Westinghouse Hanford Company, Richland, Washington.

Bernero, R. M., Director Office of Nuclear Materials Safety and Safeguards, U. S. Nuclear Regulatory Commission memorandum dated March 2, 1993 to J. Lytle, Deputy Assistant Secretary for Waste Operations, Office of Waste Management, Environmental Restoration and Waste Management, U. S. Department of Energy, Washington D.C.

Certa, P. J., 1995, Select Retrieval Sequences and Blending Strategy Decision Analysis Frame, WHC-SD-WM-RPT-107, rev. 0, Westinghouse Hanford Company, Richland, Washington.

DOE 1988, Final Environmental Impact Statement for the Disposal of Hanford Defense High-Level, Transuranic and Tank Wastes, Hanford Site, Richland, Washington: Record of Decision, Federal Register, Vol. 52, pp 12449-12453, DOE/EIS-0113, vol. II, p B.6, U. S. Department of Energy, Washington D.C.

DOE 1993, Justification of Mission Need Tank Waste Remediation System, U. S. Department of Energy, Washington D.C.

DOE-RW 1993, Estimates for the Disposal of Hanford Single-Shell Tank Waste in a Geologic Repository, memorandum dated July 13, 1993 from H. H. Brandt, Director Program Control and Administration Division, U. S. Department of Energy Office of Civilian Radioactive Waste Management to J. Tseng, Acting Director Tank Waste Remediation System Division, U. S. Department of Energy Office of Waste Management, U. S. Department of Energy, Washington D.C.

DOE 1994a, draft, Tank Waste Remediation System Functions and Requirements, DOE/RL-92-60, rev. 1, U. S. Department of Energy, Richland, Washington.

DOE 1994b, Closure of the Ferrocyanide Unreviewed Safety Question, memorandum 94-SST-052 from T. R. Sheridan, Acting Program Manager Office of Tank Waste Remediation to President Westinghouse Hanford Company, U. S. Department of Energy, Richland, Washington. 
DOE 1994c, Waste Acceptance System Requirements Document (WASRD), DOE/RW-0351P, rev. 1, U. S. Department of Energy Office of Civilian Radioactive Waste Management, Washington D. C.

Ecology, U.S. EPA and U.S. DOE 1994, Hanford Federal Facility Agreement and Consent Order, 89-10, rev. 3, Washington Department of Ecology, U.S. Environmental Protection Agency, and U.S. Department of Energy, OTympia, Washington.

Garfield, J. S., Noncompetitive Procurement of Services from Fluor Danie7 Incorporated for Preparation of TWRS Disposal Engineering Phase 3 Trade Studies, internal memorandum \#71220-94-040, dated November 30, 1994 , Westinghouse Hanford Company, Richland, Washington.

Gibson, M. W. and B. C. Landeene, September 1987, Process Flowsheet Demonstration of Neutralized Current Acid Waste Pretreatment at B Plant, PFD-B-033-00001, rev. A-1, page 9, Rockwe11 Hanford Company, Rich1 and, Washington.

Jensen, R. D., September 1994, Enhanced S7udge Washing Evaluation P7an, WHC-EP-0805, Westinghouse Hanford Company, Richland, Washington.

Lilga, M. A., M. R. Lumetta, and G. F. Schiefelbein, 1993, Ferrocyanide Safety Project, Task 3, Aging Studies FY 1993 Annual Report, PNL-8888, UC-721, Pacific Northwest Laboratory, Richland, Washington.

Lilga, M. A., E. V. Alderson, M. R. Lumetta, and G. F. Schiefelbein, 1994, Ferrocyanide Safety Project, Task 3: Ferrocyanide Aging Studies, FY 1994 Annual Report, PNL-10126, Pacific Northwest Laboratory.

MacLean, G. T., December 1994 (draft), Tank AZ-101 Sludge Washing Test, WHC-SD-WM-PTP-028, Westinghouse Hanford Company, Richland, Washington.

Orme, R. M., June 1994, TWRS Process Flowsheet, WHC-SD-WM-TI-613, rev. 0, Westinghouse Hanford Company, Richland, Washington.

Orme, R. M., 1995, Preliminary Time-Phased TWRS Process Model Results, WHC-SD-WM-TI-693, Rev. 0, Westinghouse Hanford Company, Richland, Washington.

Place, D. E., August 1991, Preliminary Evaluation - Washing of Neutralized Current Acid Waste (NCAW) Solids in Aging Waste Tanks, WHC-SD-WM-ER-125, page D-2, Westinghouse Hanford Company, Richland, Washington.

PNL 1994, An Assessment of the Dilution Required to Mitigate Hanford Tank 241-SY-101, PNLMIT:112994, Pacific Northwest Laboratory, Richland, Washington.

Ranade, A. D., Facility Life Cycle Cost Definition of Capacity for Planning Studies, internal memorandum dated February 8, 1994, Westinghouse Hanford Company, Richland, Washington.

Raytheon/BNFL 1994a, Initial Pretreatment ModuTe Trade Studies: Sludge Washing, E/B-SD-W236B-RPT-021, Raytheon/BNFL Richland, Washington. 
Raytheon/BNFL 1994b, Initial Pretreatment Module Trade Studies: In-Tank Radionuclide Separation, E/B-SD-W236B-RPT-018, Raytheon/BNFL Richland, Washington.

Raytheon/BNFL 1994c, Initial Pretreatment Module Trade Studies: Out-of-Tank Radionuclide Separation, E/B-SD-W236B-RPT-023, Raytheon/BNFL Richland, Washington.

Rizzo, A. J., Assistant Manager for Operation, U. S. Department of Energy Richland Operations Office memorandum dated March 6, 1989 to Bernero, R. M., Director Office of Nuclear Materials Safety and Safeguards, U. S. Nuclear Regulatory Commission.

WHC 1993, Radionuclide and Chemical Inventories for the Double She17 Tanks, R. J. Van V1eet, WHC-SD-WM-TI-543, rev. 1, page B-21, Westinghouse Hanford Company, Richland, Washington.

WHC 1994a, Configuration Selection for the Tank Waste Remediation System, memorandum 9454691 from W. T. Alumkal, Westinghouse Hanford Company, to T. R. Sheridan, Acting Program Manager Office of Tank Waste Remediation System, U.S. Department of Energy, Richland Operations Office, Richland, Washington.

WHC 1994b, Tank Waste Remediation System Facility Configuration Study, K. D. Boomer, et. al., WHC-SD-WM-ES-295, rev. 0, Westinghouse Hanford Company, Richland, Washington.

WHC 1994c, Tank Waste Remediation System Multi-Year Work P7an, WHC-SP-1101, rev. 0 , Westinghouse Hanford Company, Richland, Washington.

WHC 1994d, Waste Tank Summary for Month Ending July 31, 1994, B. M. Hanlon, WHC-EP-0182-76, page E-6 and E-7, Westinghouse Hanford Company, Richland, Washington.

WHC 1994e, Tank Farm Restoration and Safe Operations, Design Requirements Document, WHC-SD-W314-DRD-001, rev. 0, Westinghouse Hanford Company, Richl and, Washington.

WHC 1994f, Operational Waste Volume Projection, WHC-SD-WM-ER-029, rev. 20, Westinghouse Hanford Company, Richland, Washington.

WHC 1994g, Tank Waste Remediation System Decisions and Risk Assessment, WHC-EP-0786, rev. 0, Westinghouse Hanford Company, Richland, Washington.

Winkler, C. M., September 1993, Process Evaluation for In-Tank Washing of 101-AZ and 102-AZ S7udges, WHC-SD-WM-PE-051, Westinghouse Hanford Company, Richland, Washington. 
WHC-EP-0856

This page intentionally left blank. 


\section{DISTRIBUTION}

Number of Copies

ONSITE

6

U. S. Department of Enerqy Richland Operations office
G. H. Sanders
S7-53
L. Erickson
S7-53
D. J. Francis
S7-53
V. L. Saladin
S7-53
D. D. Wodrich
S7-50
DOE-RL Public Reading Room
A1-65

2

Pacific Northwest Laboratory

D. A. Seaver

M. A. Duffy

S7-71

K6-51

28 Westinghouse Hanford Company

D. E. Ball

S4-58

P. A. Baynes

B1-58

A. L. Boldt

H5-49

K. D. Boomer

H5-49

G. L. Dunford

S7-81

L. F. Ermold

S7-84

J. D. Galbraith

H5- 49

J. S. Garfield

H5-49

K. A. Gasper

G3-20

M. L. Grygiel

B1-59

J. 0. Honeyman

S7-81

M. E. Johnson

B1-58

C. E. Leach

H5-49

G. A. Meyer

S4-54

R. J. Murkowski

R4-01

R. W. Powell

H4-14

I. E. Reep

G3-20

J. A. Swenson

H5-49

A. M. Umek

S7-81

D. J. Washenfelder

L4-75

M. W. Wells

$57-80$

R. S. Wittman

B1-59

G. F. Williamson

R4-01

R. D. Wojtasek

S7-84

Central Files (1)

L8-04

Information Retease

Administration-(3)

OSTI

$44-17$
\[ 8-07 \] 
WHC-EP-0856

This page intentionally left blank. 